ISSN 0353-295X (Tisak) ISSN 1849-0344 (Online) RADOVI - Zavod za hrvatsku povijest Vol. 47, Zagreb 2015.
UDK 2-36Elisabeth de Thueringen, sancta Izvorni znanstveni rad Primljeno: 17. 6. 2015. Prihvaćeno: 19. 10. 2015. DOI: 10.17234/RadoviZHP.47.15

Ženu dobru aĉe kto obreĉet' ot'krainihb i dalečnih'stran' cêna ee

(Izr 31,10)

\title{
Žena, majka, svetica: Elizabeta Ugarska u latinskim i hrvatskoglagoljskim izvorima*
}

\begin{abstract}
U radu se raščlanjuju najpoznatiji latinski i hrvatskoglagoljski izvori o hrvatsko-ugarskoj princezi i tirinškoj grofici svetoj Elizabeti Ugarskoj (1207. - 1231.). Primarni se izvori odnose na dokumentaciju prikupljenu u procesu Elizabetine kanonizacije, koja je jedan od najranijih formaliziranih kanonizacijskih procesa u Crkvi uopće. Među tim je izvorima najvažniji zapis svjedočanstava Elizabetinih dvorkinja i sluškinja pred papinskom komisijom, poznat pod naslovom Dicta quatuor ancillarum (1235.), koji nudi zanimljivu žensku perspektivu i pogled na Elizabetin život, prilično različit od onoga koji iz muške perspektive u svojim književnim uspješnicama, tj. u sekundarnim izvorima nude Jakob Varaginski (Zlatna legenda, oko 1260.) i Marko Marulić (Upućenje u čestit život s primjerima svetaca, oko 1496.), iako se pokazalo da su obojica izravno ili neizravno poznavala sadržaj Dicta. Ta je razlika najuočljivija u prikazivanju i poimanju Elizabetina bračnoga života. Sekundarni i literarizirani izvor o Elizabeti jest i čtenie, koje sadrže hrvatskoglagoljski brevijari (14. i 15. stoljeće). Ustanovljeno je da je ono vjeran prijevod odabranih dijelova Dicta. Osim odnosa s Dictama, u istraživanju se raščlanjuje i odnos toga čitanja s inačicama u Varaginskoga i Marulića. Konačno, radu je priloženo kritičko izdanje čitanja o sv. Elizabeti, koje obuhvaća 14 hrvatskoglagoljskih brevijara crkvenoslavenskoga razdoblja.
\end{abstract}

\section{Plemstvo duha i plemstvo tijela}

Sveta je Elizabeta Ugarska (1207. - 1231.) jedna od omiljenih svetica franjevačke duhovnosti, zaštitnica Trećega reda sv. Franje i Franjevačkoga svjetovnog reda, ali i jedna od najpoznatijih ličnosti njemačkoga srednjovjekovnoga dvorskog života. Podrijetlom je bila Mađarica, ali je udajom za tirinškoga grofa Ludviga IV. dobila priliku djelovati i ostaviti neizbrisivoga traga u germanskom svijetu, u kojem

\footnotetext{
Ovaj je rad financirala Hrvatska zaklada za znanost projektom 2462.
} 
je poznata kao Elizabeta Tirinška/Tiringijska (njem. Elisabeth von Thüringen). Da popularnost koju je uživala još za svoga ovozemaljskoga života nije jenjala kroz nadolazeća stoljeća, pokazuje i svečano proslavljena obljetnica osamstote godišnjice Elizabetina rođenja 2007., kada je, između ostaloga, Njemačka izdala kovanicu od deset eura s likom ove plemkinje i svetice. ${ }^{1}$ Elizabetina se djevojačka plemićka legitimacija veže za ugarsku dinastiju Arpadović, krunu sv. Stjepana i hrvatsko-ugarsko prijestolje. Elizabetin otac bio je Andrija II., hrvatsko-ugarski kralj, koji se na petu križarsku vojnu uputio iz Splita i koji je taj pomorski prijevoz u Svetu Zemlju Mlečanima platio Zadrom i davanjem kraljevskih regalija templarima. ${ }^{2}$ Andrijin nasljednik i Elizabetin brat bio je Bela IV. kojega je otac još za života okrunio za mlađega kralja i imenovao hercegom Hrvatskoga Kraljevstva. ${ }^{3} \mathrm{Za}$ vrijeme svoje vladavine najdugovječniji je hrvatsko-ugarski kralj arpadovićevske krvi Bela IV. bio široke ruke kada je o privilegijima riječ, pa je tako u jednom trenutku na red došao i Gradec, kojem je Zlatnom bulom dodijeljen status slobodnoga kraljevskog grada.

Drukčije je povijest pisala Elizabeta. U kratke dvadeset i četiri godine svoga života svojim suvremenicima nije darivala ni gradove ni privilegije, nego nepropadljivo svjedočanstvo poniznosti, ljubavi i žrtvovanja za čovjeka, pogotovo onoga siromašnoga, bolesnoga i prezrenoga. Da ni takva istinska kraljevska krv nije voda, potvrđuju i ostale svete žene iz loze Arpadovića: nećakinja sv. Elizabete - sv. Margareta Ugarska (1242. - 1270.), dominikanka i kći Bele IV., rođena pred tatarskom najezdom u Klisu kraj Splita, te još jedna slavna srednjovjekovna dama, kraljica i svetica, pranećakinja Elizabete Ugarske, sv. Elizabeta Portugalska (1271. -1336.). Ne valja zaboraviti da činjenicu kako vladari i moćnici mogu biti sveti potvrđuju i muški Arpadovići: sv. Stjepan I. (975. - 1038.), sv. Emerik (oko 1005. -1031.) i sv. Ladislav I. (oko 1040. -1095.). ${ }^{4}$ No sveti vladari Elizabeti nisu bili srodni samo po očevoj lozi, nego i po majčinoj. Njezina tetka, majčina sestra, bila je poljska vojvotkinja sv. Hedviga Šleska (1174. - 1243.). Konačno, Elizabeta je imala privilegij da ju je njezin suprug grof Ludvig IV. uspješno pratio na putu svetosti te se, iako nije službeno kanoniziran, naziva svetim ili blaženim Ludvigom, posebno u njemačkom svijetu. ${ }^{5}$

Iako je i sama bila aristokratkinja, cijeli je Elizabetin život bio kritika i negacija svjetovnoga poimanja bogatstva, vlasti i moći. Zato je i bila trn u oku svoje plemićke okoline, koja ju je nekako još podnosila dok joj je muž bio živ. No nakon

Vidi Die 10 Euro Gedenkmünze ,,800. Geburtstag Elisabeth von Thüringen“.

2 Vidi RAUKAR 1997: 68.

3 Vidi RAUKAR 1997: 76.

4 Među Hrvatima u Slavoniji i Mađarskoj sv. Stjepan i sv. Ladislav posebno se štuju sve do danas (vidi FRANKOVIĆ 2010.).

5 Vidi GORYS 2003: 251. 
njegove pogibije na petom križarskom pohodu Elizabeta biva prognana zajedno sa svojom djecom te konačno živi puninu siromaštva, koje je do tada živjela u duhu. Pa i onda kada je napokon dobila svoj udovički imetak, uložila ga je u izgradnju bolnice u Marburgu, u kojoj je do kraja života skrbila za svoje štićenike, među kojima nije bila poznata ni kao kraljevna ni kao grofica, nego samo kao-majka.

\section{Elizabeta i franjevci}

Elizabeta Ugarska prva je kanonizirana žena franjevačke duhovnosti (1235.). Prije nje kanonizirani su redovnici sv. Franjo Asiški (1228.) i sv. Antun Padovanski (1232.). ${ }^{6}$

Premda je zaštitnica Trećega reda, jasno je da mu nije mogla formalno pripadati jer je red kanonsko odobrenje dobio 1289., pola stoljeća nakon njezine smrti. No i letimičan pogled na osnovne crte iz njezine duhovne biografije pokazuje da se ne može dovesti u pitanje bliskost Elizabetine duhovnosti i one franjevačke provenijencije: Elizabetin prijezir prema materijalnome bogatstvu i počastima kojima je kao plemkinja bila izložena, pokornički život, milosrdno služenje zajednici, posebno u vidu brige za siromašne i prezrene, te mistično iskustvo Kristove prisutnosti. Osim toga, srednjovjekovni biografski izvori spominju neformalne vidove njezina odnosa s franjevcima, npr. da je prela vunu i šila odjeću za fratre 7 , odnosno da se jedan mladić njezinim zagovorom pridružio franjevcima (vidi dalje).

U svojoj katehezi na svetičin blagdan papa Benedikt XVI. govori kako ju je njezin prvi duhovni vođa, brat Rüdiger, upoznao s obraćenjem Franje Asiškoga, nakon čega se ona još intenzivnije predala kršćanskome životu. ${ }^{8}$ Franjevcima je pomogla sagraditi i samostan, kojem je Rüdiger postao poglavarom. Njezin crkveni status u godinama udovištva Benedikt XVI. naziva terminom soror in saeculo (,sestra u svijetu“), koji podrazumijeva posvećen život, ali izvan redovničke zajednice. Stoga i ne začuđuje što je Franjevački svjetovni red izabrao Elizabetu za zaštitnicu: ona je formalno bila svjetovna žena, pogotovo do pogibije svoga supruga, ali je dosegla puninu posvećenosti živeći upravo u svijetu koji joj nije bio sklon. U Elizabeti su trećoredci prepoznali i zadobili vrstan uzor i moćnu zagovornicu.

\footnotetext{
Usp. BAŠIĆ 2004: 240.

7 Vidi WOLF 2010: 198.

8 Vidi BENEDIKT XVI. 2010.
} 


\section{Elizabeta u srednjovjekovnoj i ranonovovjekovnoj latinskoj književnosti}

\section{Zlatna legenda}

Jedno od najpoznatijih i najutjecajnijih književnih djela srednjovjekovne epohe svakako je Zlatna legenda (lat. Legenda aurea), zbirka svetačkih legendi iz 1273., koja je u razdoblju inkunabula imala više izdanja od same Biblije. Njezin sastavljač, dominikanac Jakov Varaginski (Jacobus de Voragine, oko 1228. - 1298.), svoju je pozornost usmjerio ponajprije na biblijske svece i svece iz ranocrkvene povijesti. Za svoje je bliže ili daljnje suvremenike osigurao svega pet mjesta, pa se u njegovoj hagiografskoj zbirci mogu čitati legende o sv. Tomi Beckettu (1118. - 1170.), sv. Dominiku (1170. -1221.), sv. Franji Asiškom (1181. - 1226.), sv. Petru Veronskom (1206. - 1252.) i, konačno, o sv. Elizabeti Ugarskoj, kao jedinoj ženi među njima i jedinoj svjetovnoj ličnosti. Može se primijetiti kako u Zlatnoj legendi izostaje Svetac Svega Svijeta, franjevac sv. Antun Padovanski, koji je već za života bio poznat po čudesima, koji je umro iste godine kao i Elizabeta, ali je kanoniziran tri godine prije nje i to u najkraćem kanonizacijskom procesu u povijesti Crkve. Ta bi činjenica mogla biti prilog tezi da je u srednjovjekovlju Elizabeta, uz Franju Asiškoga, doista bila omiljena svetica franjevačke duhovnosti. ${ }^{9}$

Život svete Elizabete u Zlatnoj legendi započinje pohvalom njezinoj svetosti, krepostima i vrlinama, a završava navođenjem šest čudesa, koja su se po svetičinu zagovoru dogodila nakon njezine smrti. ${ }^{10}$ Unutar toga okvira opisuje se Elizabetin život od djetinjstva do rane smrti, koji vrlo slikovito govori u prilog tome koliko je bila kontroverzna za plemenitaške krugove u kojima je stasala i od kojih se po mnogočemu razlikovala. Pohvaljuje se i njezina supruga, koji joj je, kako ističe pripovjedač, dao potpunu moć i vlast u svemu što je pridonosilo zdravlju njihovih duša. Osim toga, jasno je da je i dok je bila živa svojim zagovorom mijenjala ljudske živote. Tako se navodi kako se za vrijeme dok se žarko molila za nekoga mladića, koji je živio izrazito svjetovno, on osjećao kao da se nalazi usred snažnoga plamtećega ognja, koji je prestao tek kada je odlučio drastično promijeniti svoj život i pridružiti se Maloj braći. Ovaj se prizor spominje u još jednoj europskoj književnoj uspješnici, posebnoj po tome što je izišla iz pera jednoga Hrvata.

\section{De institutione bene vivendi per exempla sanctorum}

Bogato svjedočanstvo Elizabetine svetosti nalazi se i u jednom ranonovovjekovnom bestseleru, ali duboko prožetom srednjovjekovnom kršćanskom etikom i nastalom na hrvatskom tlu. Riječ je o Upućivanju u čestit život po primjerima svetaca (lat. De institutione bene vivendi per exempla sanctorum) oca hrvatske

\footnotetext{
Usp KLANICZAY 2002: 421.

10 Englesku inačicu legende o sv. Elizabeti iz Legende auree vidi na MEDIEVAL SOURCEBOOK.
} 
književnosti, Marka Marulića Splićanina (oko 1496.). ${ }^{11}$ Budući da je poznato da je Marulić bio pisac s posebnim osjećajem za ženske junakinje, ne začuđuje ni da ovo njegovo djelo ne preza od uvođenja ženskih svetačkih uzora, među kojima Elizabeta ima istaknuto mjesto. Nakon Djevice Marije najspominjanija je svetica u Upućivanju, na što referira i sam Marulić kada kaže da ,gotovo nijedna vrsta krjeposti u ovome djelu nije bez njezina primjera" ${ }^{12}$

Za razliku od Varaginskoga, koji daje podatke o Elizabetinu djetinjstvu te čudima koja su se događala nakon njezine smrti, Marulić se drži godina njezina supružništva i udovištva te podataka koji ne zadiru previše u čudesno i onostrano. Ističe Elizabetin prijezir prema zemaljskim dobrima te predanost siromaštvu i siromašnima, velikodušnost $u$ davanju milostinje, poniznost i poimanje sebe kao sluškinje, ustrajan i plodonosan molitveni život, duboka razmatranja u kojima bi joj se Bog obraćao, ljubav prema neuglednoj i pokrpanoj odjeći te ručnom radu, tj. predenju vune, tkanju i šivanju, podvrgavanje bičevanju i samošibanju, poslušnost duhovnom vođi Konradu, ćudorednu čistoću, postojano trpljenje nepravde i štete te svetu smrt. ${ }^{13}$

Što su sve bili Marulićevi izvori o Elizabetinu životu i svetosti, pitanje je čiji precizan odgovor premašuje okvire zadane ovim radom. Da je Zlatna legenda jedan od Marulićevih izvora, ne samo za podatke o Elizabetinu životu, navodi prevoditelj i priređivač prvoga cjelokupnoga hrvatskoga izdanja Upućivanja Branimir Glavičić. ${ }^{14}$ Sadržajna su podudaranja doista uočljiva kada se pročitaju inačica životopisa u Zlatnoj legendi te primjeri iz Elizabetina života u različitim poglavljima Upućivanja, pri čemu ne valja zaboraviti da je riječ o formalno različitim tipovima tekstova s različitim funkcionalnim i pragmatičkim polazištem i ciljevima.

Na ovom se mjestu može izdvojiti događaj zanimljiv obama piscima, kao dojmljiva potvrda Elizabetine beskompromisne odlučnosti. Nakon Ludvigove smrti biskup ju je bamberški blagonaklono htio izbaviti od teškoća udovištva i progona muževih rođaka, pa joj je predložio i stao je nagovarati da se opet uda. No ona je, želeći njegovati čistoću izvan braka i podnositi sve nedaće udovištva i progonstva, odgovorila da će sama sebi odrezati nos kako bi bila odbojna svakomu muškarcu. Nasreću, to je ušutkalo biskupa, pa je Elizabetin nos ostao ondje gdje mu je i mjesto.

\footnotetext{
${ }_{11}$ Nije zgorega podsjetiti na činjenicu da je ovu Marulićevu književnu uspješnicu u torbi nosio i revno proučavao i sam sv. Franjo Ksaverski, čijim se imenom zove samostan zagrebačkih trećoredaca, na svojim misijskim putovanjima u Aziji.

12 MARULIĆ 2010: 316.

13 Vidi MARULIĆ 2010: 20, 34, 52, 74, 100, 110, 120, 210, 220, 224, 257, 258, 316, 386, 395 , 474.

14 Vidi MARULIĆ 2010: 575.
} 


\section{Povijesno-pravni srednjovjekovni latinski izvori o Elizabeti}

U prethodnom je naslovu rečeno kako je vjerojatno da je Marulićev izvor ili jedan od izvora za primjere čestitosti Elizabetina života bio njezin hagiografski prikaz u Zlatnoj legendi. No vrlo bi se vjerojatno moglo reći i da je sadržajno podudaranje ovih dvaju prikaza Elizabetine svetosti rezultat zagledanja u jedan drugi izvor, odnosno da su oba literizirana prikaza nastala na temelju drugoga izvora, ne više hagiografsko-književnoga karaktera, nego povijesno-pravnoga.

Naime, zašto je Elizabeta postala važna povijesna ličnost sve do današnjih dana proizlazi iz činjenice da je njezin kanonizacijski proces jedan od prvih formalno pokrenutih i službeno dokumentiranih kanonizacijskih procesa u povijesti Crkve, odnosno za tu su priliku prikupljeni i sastavljeni dokumenti jedni od rijetkih iz toga razdoblja sačuvani sve do danas. ${ }^{15}$ Ta kanonizacijska dokumentacija obuhvaća opsežan popis od 130 prijavljenih čudesa, koja su se dogodila nakon Elizabetine smrti i koja su opisana pred dvama papinskim povjerenstvima za kanonizaciju, zatim Summu vitae iz pera njezina duhovnoga vođe Konrada, sastavljenu za papu Grgura IX., koji je i pokrenuo proces Elizabetine kanonizacije te, konačno, za Elizabetin život najrelevantniji i najsadržajniji dokument, svjedočanstva i iskaze njezinih dvorkinja i sluškinja, izrečene također pred papinskim povjerenstvom u siječnju 1235. i poznate pod naslovom Dicta quatuor ancillarum (hrv. Izjave četiriju sluškinja).

Svi ti dokumenti iz kanonizacijskoga procesa predstavljaju primarne izvore o Elizabetinu životu ${ }^{16}$, dok su oni književni ili literarizirani, o kojima je riječ u ovome radu, sekundarni izvori.

\section{Dicta quatuor ancillarum}

Kada se pročitaju Dicta quatuor ancillarum, jasnom se pokazuje činjenica da su, izravno ili neizravno, poslužile kao izvor i Zlatnoj legendi i Upućivanju. No još je važnije naglasiti da je riječ o tekstu relevantnome ne samo za svijet franjevačke ili katoličke duhovnosti, nego i uopće za medieviste, književne povjesničare i teoretičare, sociologe, antropologe i ostale humaniste, ali i za sve one željne pogleda u život osebujne srednjovjekovne plemkinje. Posebnost je Dicta sadržana u činjenici da su, za razliku od ostalih dostupnih i sačuvanih izvora o Elizabeti, sastavljene iz ženske perspektive. Riječ je o zapisu svjedočanstava koje su pod zakletvom izrekle Elizabetine četiri najbliže suradnice, dvorkinje i sluškinje, koje su s njom živjele iz dana u dan, iz godine u godinu. Njihova su imena Guda, Isentruda, Irmengarda i Elizabeta. Takva perspektiva ne samo da na svjetlo dana

\footnotetext{
Vidi PIEPER 2002: 312; WOLF 2010: 4.
}

16 Engleski prijevod spomenutih primarnih izvora donosi se u WOLF 2010. 
iznosi brojne detalje o Elizabeti, kakve ostali izvori ne spominju, nego i sve ono što je izrečeno, izrečeno je otvorenije, slobodnije i drukčije nego što bi kakvo androcentrično polazište bilo spremno napraviti.

Najuočljivije se to očituje u načinu kako je prikazan Elizabetin brak. Ona se, naime, kao sretno udana žena, tj. supruga i majka nije posve uklapala u srednjovjekovne okvire, u kojima je dominirala figura svetice-djevice i svetice-mučenice. I zato se prikaz njezina bračnoga života razlikuje kod muških autora, Konrada, Varaginskoga i Marulića, te kod ženskih svjedokinja Dicta. ${ }^{17}$ Konrad u svome pismu papi navodi kako je u trenutku kada ju je upoznao već dvije godine bila udana te da je bila uzrujana što svoj ovozemaljski život neće okončati kao djevica. ${ }^{18} \mathrm{U}$ istom tonu Varaginski pripovijeda da je Elizabeta pristala na brak iz poslušnosti prema ocu, iako je njezina želja bila da se ne uda. Varaginski ide još i dalje, navodeći vrlo upitan podatak koji ne sadrži nijedan poznati izvor, a pogotovo ne Dicta, da je upravo Elizabeta nagovarala supruga da ode u križarski rat, u kojem je konačno i poginuo. Marulić je pak nekako „prešao" preko sretnoga braka, ali na način da je ustanovio, opet prema zasada nepoznatom izvoru, da je Elizabeta ,ishodila od muža da se uzdržavaju noću“. ${ }^{19}$ Zanimljivo je da i Varaginski i Marulić u svoja djela uklapaju prizor iz bračne ložnice, sadržan u Dictama, o tome kako se Elizabeta često molila noću, ali prešućuju, za muško oko možda nevažan detalj, da ju je suprug pritom nježno držao za ruku. Marulić spominje i sag na kojem se znala moliti, ali ne navodi nastavak dijaloga između sluškinja i Elizabete, koja im kaže da je ostala ležati na tlu želeći trpjeti pokoru odvajanja od svoga voljenoga supruga. Odvajanja, stoga, očito nije bilo onda kada Elizabeta ne bi ostala spavati na sagu. U Dictama se, osim toga, izričito kaže da se Elizabeta zavjetovala na uzdržljivost u slučaju da nadživi svoga supruga, a ne za njihova života. Elizabetine prijateljice svjedoče i kako se mladi bračni par volio s čudesnom privrženošću jedno drugomu te da je Elizabeta, pokapajući svoga muža, s kojim je izrodila troje djece, izjavila da kada bi ga mogla vratiti, radije bi izabrala suživot s njim u prosjačenju negoli cijeli svijet. Da je glasovita ljubav dvoje supružnika bila plodonosna i nakon Elizabetine smrti, pokazuje popis čudesa s prvoga papinskog povjerenstva, u kojem se nalazi svjedočanstvo žene imenom Matilda. Matilda je slušala lirske pjesnike minezingere kako pjevaju o tužnom rastanku Elizabete i Ludviga pred njegov put u Svetu Zemlju. Pjesma ju je dirnula pa je zaplakala, pri čemu joj se vratio ranije izgubljen vid na desno oko. ${ }^{20}$

\footnotetext{
Usp. PIEPER 2002: 312.

Vidi WOLF 2010: 92.

19 MARULIĆ 2010: 100 .

20 Vidi WOLF 2010: 154.
} 
Iako su tematski vezane za život ispunjen odricanjima, patnjama i nepravdama, zbog detaljnoga prikazivanja života neobične junakinje Dicta se pokazuju i kao prilično zabavno štivo. Dok muški posrednici Elizabetine priče navode kako je ili svojevoljno bila bičevana od Konrada i svojih sluškinja ili je fizički kažnjavala samu sebe, samo se u Dictama može saznati da je Elizabeta očito smatrala kako je ono što je dobro za nju dobro i za njezinu okolinu, pa je i ona bila ta koja je išibala neku ženu, kako bi je natjerala da pristupi sakramentu ispovijedi. A da je bila poslušna samo ondje gdje je smatrala da to treba biti, pokazuje događaj s jednom nadstojnicom samostana, koja ju je primorala da se ode okupati. Elizabeta je u kupku ušla samo jednom nogom, tj. stopalom, promućkala vodu i zaključila da je zahtjev časne majke ispunjen. Drugom je prilikom objedovala zajedno sa svojim sluškinjama i kada joj je jedna od njih priznala da je oduševljena jer može s njom sjediti za istim stolom, Elizabeta je odgovorila kako bi zapravo još primjerenije bilo kada bi joj sluškinja sjela u krilo, na što ju je onda stala nagovarati i - uspjela.

Kao što je ranije rečeno, uvidom se u cjelokupne Dicta jasno uviđa da je ovaj, u svojoj biti pravni dokument, poslužio kao temeljni izvor i Varaginskom i Maruliću, unatoč tomu što su u pitanju njezina braka bili skloniji vlastitom viđenju i tumačenju, nego onome što su o tome posredovale Elizabetine družice. Na ovom mjestu valja dodati i potvrđenu pretpostavku da se Marulić, kao izvorom za primjere o Elizabeti, nije služio samo Zlatnom legendom. Primjerice, Zlatna legenda ne sadrži opis Elizabetine brige i skrbi za dječaka koji je patio od proljeva te za gubavu ženu, za razliku od poglavlja $O$ tome kako treba težiti za poniznošću Marulićeva Upućenja. No ovaj se podatak, osim u Dictama, može naći i u Konradovoj Summi vitae. To pak ne vrijedi za iznos od 2.000 funti Elizabetina miraza, koji je Marulić mogao saznati zahvaljujući svjedočanstvima njezinih najbližih suradnica.

Svakako valja zaključiti da je dragocjena prednost Dicta ta što Elizabetu predstavljaju kao svestranu ženu od krvi i mesa, dajući dubok uvid u njezin višeslojan karakter. Suvremenim filmskim rječnikom rečeno, za razliku od sekundarnih izvora, obilježenih svjetonazorom svojih autora i funkcionalnom pripadnošću njihovih tekstova, Dicta kao da Elizabetinu priču posreduju u 3D verziji, verziji koja posebno odgovara publici. Nasreću, u toj su je verziji, između ostalih, imali prilike upoznati i posredovati najmarljiviji kulturni djelatnici hrvatskoga srednjovjekovlja - glagoljaši.

\section{Elizabeta u hrvatskoglagoljskim izvorima}

Hrvatskoglagoljski izvori o kojima je riječ obuhvaćaju misale, brevijare, psaltire, rituale i zbornike iz 14. i 15. stoljeća. Riječ je o tekstovima koji su se prevodili i uređivali s latinskoga ili grčkoga predloška, a ne o autorskim tekstovima. Jezik na koji su glagoljaši prevodili u paleoslavističkoj se filologiji zove hrvatski crkve- 
noslavenski. ${ }^{21}$ Riječ je o prvom hrvatskom književnom jeziku, jeziku Bašćanske ploče (oko 1100.), kao i o jeziku prve hrvatske tiskane knjige, Misala po zakonu rimskoga dvora (1483.).

\section{Ime}

U hrvatskoglagoljskim izvorima mogu se naći dvije inačice Elizabetina imena, koje svjedoče o dvojakom izvorištu fenomena hrvatskoga glagoljaštva: istočno-ćirilometodska Elisavta prema grčkome 'E $\lambda ı \sigma \alpha ́ \beta \varepsilon \tau$ te zapadnoeuropska Elizabêtb prema latinskome Elisabeth. ${ }^{22}$ Potonja je inačica ujedno i češća u zadanome korpusu. U brevijarima, koji sadrže čitanje o Elizabeti, oblik je Elisavta potvrđen u IV. vrbničkom i Metropolitanskom brevijaru te u Brevijaru popa Mavra. Potvrđen je i u najstarijem hrvatskoglagoljskom misalu, Vatikanskom misalu Illirico 4 (početak 14. stoljeća).

Zanimljivost je ovoga oblika sadržana u činjenici da su glagoljaši pred sobom imali latinske predloške jer je Elizabeta katolička svetica, a tako i polazišni oblik Elisabeth. Stoga su grčku inačicu Elisavta morali uvoditi samoinicijativno, vjerojatno u analogiji s imenom majke Ivana Kristitelja, sv. Elizabete. Taj je pak naziv u okviru Evanđelja po Luki potvrđen još u kanonskim starocrkvenoslavenskim tekstovima, koji su se prevodili s grčkoga predloška (u inačici Elisavetb), kao i u različitim hrvatskoglagoljskim spomenicima (u inačici Elisavta). ${ }^{23}$

\section{Spomenici i tekstovi}

Najbolja poznavateljica glagoljskih kalendara i sanktorala, Marija Agnezija Pantelić, navodi kako je Elizabetin kult bio obvezan za cijelu Crkvu. ${ }^{24}$ Štoviše, iako Elizabetin spomendan uvrštava i u registar franjevačkih svetkovina, Pantelić ga definira kao dio tzv. Panonsko-slavenskoga fonda svetkovina, koji, između ostaloga, čine i ,sveci mađarske krune, koji su vrlo rano ušli u glag. kalendare“. ${ }^{25}$ Elizabeta stoga u liturgiju ulazi vrlo brzo nakon smrti i kanonizacije, u istom stoljeću u kojem su upravo franjevci proveli reformu i redakciju plenarnoga misala i brevijara (13. stoljeće).

Osim u okviru kalendarā za mjesec studeni, sadržanima u misalima, brevijarima i psaltirima ${ }^{26}$, Elizabeta se zaziva i u litanijama, npr. u Baromićevu brevijaru

\footnotetext{
$21 \quad$ Vidi HCSL 2014.

22 Vidi i RCJHR 2011: 473.

23 Za starocrkvenoslavenski Elisavetb vidi SLOVNÍK 1968: 570-571. Za hrvatski crkvenoslavenski Elisavta vidi RCJHR 2011: 480.

24 Vidi PANTELIĆ 2013: 659.

25 PANTELIĆ 2013: 664.

26 O kojim je sve hrvatskoglagoljskim spomenicima riječ, kada su kalendari u pitanju, vidi BAŠIĆ 2004: 240-241.
} 
(159b) stoji: $s$ (ve)ta elizabetb mo(li) za (nasb). U litanijama se Elizabeta navodi i u Pariškom zborniku (1375.) te u trećoredskom Klimantovićevu obredniku (1501. - 1512.).

U Oxfordskom pak zborniku (15. stoljeće) inačica Prenja Isusa s đavlom, nazvana Učenie nedile prve posta po Mateju, na svom kraju donosi bogato oprimjerenu apologiju te pohvalu postu i molitvi, kao sigurnim sredstvima i putevima u raj. U dugom nizu nabrajanja tko je i što postigao molitvom i postom za primjer je dana i Elizabeta Ugarska: postom' i m(o)l(it)voju elizabêtu $k$ s(ve)tih' čislu pridruži (COxf 51a).

U misalima se na spomendan svetice navode misne molitve. Primjerice, u gore spomenutome Vatikanskome misalu Illirico 4 čita se: Tvoih'sr(db)ca vêrnihb b(ož)e m(i)l(o)srdi posvêti i b(la)̌̌(e)nie elisavti propovêdani slavnimi stvori nasb naslaždeniê mirskaê nenavidêti i n(e)b(e)skim' utêšeniem' vsbgda radovati se (MVat ${ }_{4} 222 \mathrm{c}$ ). Ova se molitva nalazi i u brevijarima na početku čitanja o Elizabeti. U misalu se dodaje i sljedeće: Dari m(o)l(imb) te g(ospod)i b(ož)e $n(a)$ šego obêtovaniê prinosim' da tebê ugodni a nam'sp(a)s(i)telni b(la)ž(e)nie elisavti čistim 'm(o)leniem'da vzdadet se (...) M(ol)im(b) te vs(e)m(o)gi b(ož)e da eže sp(a)sitelnimi spodobil' esi naučiti tainami b(la)ž(e)nie elisav'ti hodataistvo slavnoe nasb da nasitit'picami (MVat $\left.{ }_{4} 222 \mathrm{c}\right)$. Budući da se u srednjem vijeku sv. Poncijan papa slavio isti dan kada i Elizabeta Ugarska, misali sadrže uputu da se na taj dan prednost daje Elizabeti: $V d(a) n b$ s(ve)te elisavti ničtože ne činimo ot $s(v e) t(a) g o$ pon'ciêna $m(u)$ č(eni)ka ko naprêd' prêmičet se (MVat ${ }_{4} 222 \mathrm{c}$ ). Slična se primjedba može naći i na kraju čitanja o Elizabeti u brevijarima.

Upravo je to slikovito i dojmljivo čitanje sadržajno najrelevantniji tekst o Elizabeti u zadanome korpusu i temeljni predmet ovoga istraživanja. Tim više što u današnjim brevijarima, $\mathrm{tj}$. časoslovima ono izostaje te je zamijenjeno odabranim i odmjerenim dijelovima ranije spomenute Summe vitae Elizabetina duhovnoga vođe Konrada, koji ističe njezine vrline služenja potrebitima te njezinu duboku kontemplativnost. ${ }^{27}$

\section{3. Čtenie}

Hrvatskoglagoljsko čtenie, tj. čtenje o svetoj Elizabeti može se naći u sanktoralima brevijara, koji sadrže oficije za studeni, pa tako i za svetičin spomendan (19. studenoga). Sadržajno predstavlja vjeran prijevod odabranih dijelova Dicta. Njegovo transliterirano i kritičko izdanje, koje uključuje inačice u 14 glagoljskih brevijara, donosi poglavlje 6. Tekstovi.

Čitanje, veličine oko 600 riječi, tematski se može podijeliti na pet dijelova. Prvi je ujedno i temeljna Elizabetina duhovna legitimacija. Otvara se in medias

$27 \quad$ Vidi ČASOSLOV 1985: 1219-1220. 
res prizorom u kojem Elizabeta vlastitim rukama u vlastitom domu pere i čisti nekoga prosjaka, čije se stanje opisuje dvaput upotrijebljenim pridjevom gnusanb, te polaže njegovu glavu u svoje krilo. Tek nakon toga kratkoga opisa umeće se njezina obiteljska legitimacija: Biše bo deci krala ugrsk(a)go im(e)nemb andriê - obakb žena premoĉna i plemenita vladiki lan'grata prin'čipa paladina $\left(\mathrm{BrVat}_{6}\right.$ 200c). Nakon te rečenice čitatelj može saznati da su tu visoku plemkinju njezine sluškinje korile zbog ponašanja prema prosjaku, a ona se na to samo smijala. Ta je zgoda vezana za vrijeme kada je Elizabeta još bila u braku, a prema Dictama je prenose i Varaginski i Marulić. Nije teško razumjeti zašto se ponavlja iz izvora u izvor. Činjenica da Elizabeta prima siromaha u svoj bogati dom i da ga sama čisti i pere govori o dosegu predanosti ideji siromaštva. Ona ne izlazi na ulice davati milostinju siromašnima niti šalje svoje sluškinje da se time bave. Njezin je pristup osoban $\mathrm{i}$ intiman. Činjenica pak da dopušta svojim sluškinjama da je kore i ne vrijeđa se na to, nego se smije poput djeteta uhvaćenoga u nestašluku, govori o njezinoj poniznosti i jednostavnosti.

Druga je cjelina posvećena prizoru iz bračne ložnice mladoga tirinškoga para, koja suptilno svjedoči o skladnom braku i međusobnoj privrženosti bračnih partnera. Elizabeta je i noću ustajala kako bi se molila Bogu, a za to vrijeme njezin suprug, zabrinut i žalostan zbog njezine neugode, ruku ee v's'voei $d r$ 'žaše (BrMosk 237c), moleći je da se vrati u postelju. Kako ne bi ometala i zabrinjavala svoga grofa, Elizabeta bi zamolila svoje službenice da je probude kada oboje zaspu, kako bi se mogla moliti ne uznemirujući nikoga. Kao što je ranije spomenuto, taj prizor, koji su u Dictama posvjedočile najbliže Elizabetine družice, prenose i Varaginski i Marulić, ali ispuštajući detalj o držanju za ruke. Valja napomenuti da se nastavak noćnih događaja može čitati i u Dictama i u Zlatnoj legendi. Elizabeta je, naime, od svojih službenica zatražila da je probude na molitvu tako da je prime za noge, tj. stopala kada i ona i suprug zaspu. No jedne se noći grofova noga, kako svjedoče službenice, našla na strani kreveta njegove pobožne supruge, pa iako trgnut iz sna, Ludvig nije zamjerio, praveći se da ne primjećuje Elizabetin propali plan.

Treći je dio nešto opsežniji od ostalih četiriju, a posvećen je dubini Elizabetinih razmatranja, čiji je učinak bila njezina fizička iscrpljenost, ali i bliskost s Bogom. U hrvatskoglagoljskim se izvorima ne spominje pogibija Elizabetina muža, ali se iz Dicta može saznati da se ovaj događaj zbio nakon što je Elizabeta postala udovicom. U njemu je opisano kako se jednoga korizmenog dana u Elizabetinoj kontemplaciji, praćenoj izmjenama smijeha i plača, Bog objavljuje svojoj službenici nakon što ona izrazi želju da bude s Njim i da s Njim ostane zauvijek. Sve se to otkriva zahvaljujući znatiželji Elizabetine službenice Šendrute, koja uporno moli svoju gospodaricu da joj otkrije što je vidjela i čula. Elizabeta joj udovolji i odgovara: Vidêhb n(e)bo otvrsto $i$ onogo sladkago i(su)sa h(rbst)a g(ospod)a moego preklon'ša se kb mni $\cdot$ i utišajuca me ot vsihb tugb i ot vsihb skrbb moihb eže obidu me (Met 444a). Dok Dicta obiluju primjerima Elizabetine pokornosti 
i ljubavi prema siromaštvu, ovo je jedini koji govori o dosegu njezina osobnoga odnosa s Bogom, koji joj se izravno obraća. Stoga ne začuđuje što ga prenosi i Varaginski te u nešto kraćoj inačici od hrvatskoglagoljske i Marulić.

Četvrti dio opet uvodi u priču Elizabetina oca, hrvatsko-ugarskoga kralja Andriju, koji šalje kn(e)za im(e)nemb p'viê (BrMavr 307a) da dovede njegovu kći natrag u domovinu jer je čuo da princeza i grofica živi kao prosjakinja, lišena svake ugode. Imenovani knez ostade zaprepašten dotada neviđenim prizorom jer nikol(i)že h'ĉi kraleva videna e(stb) v(e)ce vlnu pred(u) ĉi (BrMavr 307a). Vratio se kući neispunjene zadaće jer se Elizabeta nije dala osloboditi svoga siromaštva i izgnanstva. Kako je na to reagirao kralj Andrija, ne može se saznati ni u Dictama. No važnije je da se iz cijele zgode opet iščitava Elizabetina zauzetost i predanost idealu siromaštva i služenja drugima. Ona prede vunu, tka i šije odjeću za siromašne te odbija povratak u domovinu i na očev dvor. Marulić u Upućenju na nekoliko različitih mjesta spominje da je Elizabeta odbila pozive svoga oca, ali ne opisuje ovaj konkretan događaj onako kako su to učinile „pripovjedačice“ u Dictama, a od njih prenijeli Varaginski i hrvatski glagoljaši.

Konačno, peti dio čitanja govori o vremenu kada Bog, kako sama Elizabeta kaže, one koji sutb priêteli ego prizovetb $\left(\mathrm{BrVb}_{4} 85 \mathrm{~b}\right)$. Budući da mu je Elizabeta bila dobra prijateljica, usnula je kao prava svetica: njezino tijelo nije zaposjeo smrad, nego upravo suprotno; iz njega su se stali širili miomirisi, okrepljujući ljude koji mu stajaše u blizini. Možda ih je to potaknulo da počnu otkidati komade njezine odjeće, kose i noktiju, što je ujedno i podatak kojim završava hrvatskoglagoljsko čitanje o Elizabeti. Podatak o miomirisima Elizabetina tijela spominju i Marulić i Varaginski. Osim toga, Varaginski također navodi da su otkidani dijelovi njezine odjeće i kosa. Nokte ne spominje. Ali zato se sluškinje ne daju smesti u nabrajanju, pa svjedoče da je Elizabeta ostala i bez ušiju i bez bradavica na grudima. Zbog zadanosti njihove forme i publike kojoj su bili namijenjeni, jasno je da podaci o grudima jedne plemkinje nisu mogli naći mjesta u ostalim ovdje raščlanjenim izvorima, ali su zato još jedna potvrda o različitoj i za srednji vijek neobičnoj perspektivi zanimljivoga štiva sadržanoga u tekstu Dicta quatuor ancillarum.

\section{Važnost i značenje hrvatskoglagoljskoga čtenija o Elizabeti}

Netom opisano i s ostalim izvorima uspoređeno hrvatskoglagoljsko čitanje skladna je i zaokružena cjelina, koja dojmljivo i sugestivno prenosi najvažnije posebnosti Elizabetina karaktera i svetosti. Njegov latinski sastavljač nije imao laganu zadaću jer je valjalo izabrati između mnoštva događanja, koja su mu, zahvaljujući Dictama, stajala na raspolaganju, a ograničavala ga je zadana veličina čitanja. Ipak je to samo jedno od mnogih čitanja koja se mogu naći o različitim svecima u sanktoralu nekoga brevijara. U svakom slučaju, i latinski original i 
njegova hrvatskoglagoljska inačica pred čitatelja donose jednostavnu i veselu Elizabetu. Ne spominju se pokore, bičevanja ni odsječeni nosovi, kao ni poniženja i progonstva koja je trpjela od svojih ,plemenitih“ suvremenika. Elizabetin se karakter ne pokazuje opisivanjem izvanrednih vanjskih okolnosti kojima je bila izložena niti se tumači sa stajališta kršćanskoga moralnoga nauka, nego se jednostavno daje uvid u njezinu svakodnevicu, i to onaj mirniji dio njezine svakodnevice. No izbor je to koji jednako uspješno daje do znanja koliko je bila svestrana ličnost: visoka plemkinja, majka siromaha, voljena supruga, mističarka, prelja i tkalja, čudotvorka. U ovom se čitanju otkriva ono što su njezine dvorkinje u Dictama posebno istaknule, a to je Elizabetino veselje i radost, odnosno činjenica da se nikada nije žalila ni na što, a kamoli očajavala. Upravo suprotno, baš onako kako svjedoči i hrvatska crkvenoslavenska rečenica: Veselo načetb smiêt $i$ se preslat'ko vb velici veselii lica (BrVinod 130b). Može se zaključiti da je cijelo hrvatskoglagoljsko čitanje, kao i njegov latinski original, književno vrijedan tekst koji ispunjava svoju dvojaku svrhu: sugestivno upoznavanje čitatelja sa svetičinim životom, kao poticaj i primjer njegovu osobnom duhovnom rastu.

Jedan je od dragocjenih prizora, koje za srednjovjekovnoga, ali i suvremenoga čitatelja posreduje ovo čitanje, onaj iz Elizabetine i Ludvigove bračne ložnice. Riječ je o jednom od rijetkih sretnih bračnih prizora u hrvatskoglagoljskoj književnosti uopće. U njoj, čini se, prevladavaju oni malo manje zavidni supružnički odnosi. Primjerice, u Marijinim se mirakulima iz Petrisova zbornika može čitati o jednom drugom vitezu, koji je svoje istinsko blago, tj. svoju dobru i pobožnu ženu prodao vragu kako bi stekao materijalno bogatstvo. Osim toga, Mirakuli donose i priču o sukobu žene i ljubavnice nekoga nevjernoga muža. U hrvatskoglagoljskoj književnosti problematičnost bračnoga života proizlazi i iz odluka svetaca, koji ga odbijaju s namjerom da žive kao sveci. Tako se u legendi o sv. Alekseju iz Berčićeve zbirke navodi podatak da je Aleksej na dan vjenčanja napustio svoju mladu i otišao daleko od kuće živjeti kao prosjak. Glagoljašima nisu bile nepoznate ni legende o sv. Katarini ili sv. Julijani, koje su mučenički nastradale jer se nisu htjele udati. U takvom je kontekstu brak kao nešto dobro i poželjno, odnosno Elizabetina i Ludvigova bračna ljubav bila dobrodošla promjena, ali i ohrabrenje za one koji su željeli živjeti u svijetu i u braku bez toga da ih mimoiđe sreća i svetost.

Navedeno značenje i važnost hrvatskoglagoljskoga čtenija o Elizabeti Ugarskoj proizlaze iz same vrijednosti Dicta quatuor ancillarum, koje su latinskomu priređivaču čitanja, a tako i njegovoj hrvatskoj crkvenoslavenskoj inačici bile temeljni izvor. U prilog tomu jasno govori činjenica da se u čitanju spominju imena njezinih družbenica, naravno, onih koje sudjeluju u danim prizorima. To je ono što ovo čitanje razlikuje i od Konrada i Varaginskoga, čija su djela nastala prije ovdje raščlanjenoga čitanja, te Marulića, čije je Upućenje nastalo nakon njega. Sva trojica muških posredovatelja Elizabetine priče spominju njezine sluškinje i dvorkinje, ali ih ostavljaju neimenovanima i anonimnima. U hrvatskoglagolj- 
skom se pak čitanju dvije od njih ukupno četiriju uvodi u povijest i na hrvatskom crkvenoslavenskom jeziku, tj. pred hrvatske srednjovjekovne čitatelje. Riječ je o Šendrudi (Šendruti, Sendrudi), tj. o Isentrudi, koja je svjedočila Elizabetinu kontemplativno-mističnom iskustvu, te o Irmengardiji (Irmengarda), koja je bila uz svetičinu smrtnu postelju.

Konačno, ne valja zaboraviti činjenicu da su primarni izvori o Elizabetinu životu bili dostupni rijetkima, samo onima koji su poznavali latinski jezik. I dva su najpoznatija sekundarna izvora, književne uspješnice Zlatna legenda i Upućivanje $u$ čestit život po primjerima svetaca, napisani latinicom na latinskom jeziku, tj. bili su dostupni samo učenima. Hrvatskoglagoljsko čitanje zabilježeno je glagoljicom na vernakularnom, hrvatskom crkvenoslavenskom jeziku. Tako su lokalni svećenici, đakoni, redovnici, redovnice i dr. koji su čitali oficije Elizabetinu priču mogli posredovati upravo onima s kojima se ona voljela poistovjetiti, s pučanima udaljenima i zaboravljenima od dvora. Prevodeći, uređujući i prepisujući čitanje o Elizabeti Ugarskoj, hrvatski su glagoljaši u hrvatsko društveno i kulturno ozračje prenijeli dobrodošle karakteristike „ženskoga pisma“, sadržanoga u Dictama, upoznali ga s jednom vrsnom ženom, koja je kao ugarsko-hrvatska princeza bila dijelom i domaće povijesti, te tako pridonijeli njegovanju vrijednosti za koje se zalagala i koje je svojim iznimnim životom posvjedočila. Upravo je u tome sadržana vrijednost ovoga čitanja, ne samo za hrvatsko kulturno stvaralaštvo, nego i za franjevačku duhovnost uopće.

Naposljetku, hrvatski crkvenoslavenski prijevod Dicta quatuor ancillarum, sadržan u čitanju o Elizabeti Ugarskoj, još je jedan primjer književne raznolikosti hrvatskoglagoljskih brevijara, koji, između ostaloga, sadrže i brojna druga čitanja o različitim svecima i sveticama. Jednom kada sva budu pročitana, opisana i identificirana, potvrdit će se da su brevijari istinski tezaurusi srednjovjekovne pismenosti, a tako i vjerodostojni posredovatelji srednjovjekovne epohe, relevantni jednako za hrvatsku povijest, kao i za njezin europski kontekst.

\section{Tekstovi}

Kritičko je izdanje čtenija na spomedan sv. Elizabete Ugarske pripremljeno prema fotografijama izvornika, koje se čuvaju u knjižnici Staroslavenskoga instituta u Zagrebu. Kraćene riječi razrješuju se u okruglim zagradama ( ). Nužna, ali ispuštena slova označena su šiljastim zagradama $<>$. Istim zagradama, ali s trotočjem $<$... $>$ označena su nečitka mjesta, koja se ne mogu sa sigurnošću rekonstruirati. Ispuštanje riječi bilježi se oznakom om.; dodatak tekstu oznakom praec., ako prethodi dotičnom mjestu, i oznakom add., ako slijedi za njim; nečitke se riječi bilježe oznakom illeg.; pogreška oznakom (sic!); tekst zabilježen na marginama oznakom marg.; kraj teksta, u slučajevima kada se mjesto završetka razlikuje u 
spomenicima, bilježi se oznakom finis. U transliteraciji se poštuje izvorna interpunkcija osnovnoga teksta, a inicijali su označeni masno. Velika su slova ostavljena kao i u izvornom tekstu. Vlastita se imena navode velikim slovom, što nije u skladu s izvornim tekstom. Zato su takva velika slova označena kurzivom. Osnovni je tekst onaj iz I. ljubljanskoga (beramskoga) brevijara (BrLab). Podijeljen je prema rečenicama, a njegov kritički aparat donosi fonološke, morfološke, sintaktičke, leksičke i sadržajne varijante iz ostalih 13 hrvatskoglagoljskih brevijara.

Hrvatskoglagoljsko

čtenie o sv. Elizabeti Ugarskoj

sastavljeno prema

Dicta quatuor ancillarum

I. ljubljanski (beramski) brevijar

kraj 14. st., f. 154a-154d.

${ }^{1} \mathrm{Na}$ d(a)nь s(ve)tie Elizabêti · or(a)cii · ${ }^{2}$ Tvoihь sr(bd)ca vêr'nihь b(ož)e m(i)1(o)srdb prosv(ê)ti · i b(la)ž(e)nie Elizabeti · pros'bami sl(a)vnimi · stvori ni za ljub(a)vb tvoju mir'ska naslaždeniê nenavidêti · i n(e)b(e)skago dara pričeĉeniem' vsgda radovati se $\cdot \mathrm{g}$ (ospode)mb

3čten'ie · B(la)ž(e)na Elizabêt' oĉe stoeĉi v' oblačilê mir'scêi · etera nemoĉ'na pros'êka g'nus'na zrakoms bolêz'niju glavi truždajuĉa se · taino poêm'ši · vlaĉima rukama svoima ostrigaše gnus'nie vlasi ego · k nadrom' svoim' glavu ego priklon'ši · i potom omi gl(a)vu ego taino v' vr'tê svoemb hoteĉi se skriti ot zraka č(lovêčs)skago · ${ }^{4}$ bêše bo deĉi krala ugr'skoga $\cdot$ im(e)nemb $A$ n'drêê $\cdot$ na obakb žena premoĉ'na i plemenita · lan'grata prin'čipa paladina ${ }^{5}$ Togo radi prišad'še rabi ee karahu ju ' ona že smêêše se ·

${ }^{6}$ Čten(ie) $\cdot \mathbf{B}($ la)ž(e)na Elizabêt' · često v' noĉi na m(o)l(i)tvu v'staêše · proseĉi muža da ne stužal' se bi · I I egda si ruku ee v' svoei dr'žaše · eliko dl'go m(o)laše - m(o)le ju vratiti se · ot š'kodi ee pečalan' ${ }^{8} \mathrm{~B}(\mathrm{la}) \mathrm{ž}(\mathrm{e})$ na že Elizabêt' · pače čeĉe m(o)li službenice eže za neju hoêhu · da ju noĉiju k' m(o)l(it)vê vzbujale bi · êko kimiždo noč'mi obikati v'staêše · gda ljubo muž ee s'pal' bi mogla se bi iz'neti ·

${ }^{9} \mathrm{~V}$ et'ri že d(a)nь v' koriz'mi · preklon'ši kolêna m(o)laše se pri stêni pres'bož'ne · imuĉi oči vpr'tê k' ol'taru · ${ }^{10}$ Čte(nie) · I Egda opet' v'rati se k' smêrenomu stanu svoemu ' i malo picee priêt' - êko vel'mi slaba bê · načet' misliti i nasloni se na stênu · i pod'êta bê lonom' Sen'drudinomb ${ }^{11}$ Vse iz'gnav'ši t'kmo malo rabь ostavl'ši s' soboju · oči v'prtê imêše k ponêstrê otvr'stê obraĉenê · veselo načet' smêêti se i preslat'ko v' velicê vesel'i lica.

${ }^{12}$ Čten(ie) · Po m'nozê že časê zatvori oči · i ispusti sl'zi · potom' pomalu otvori oči · i opet' počet' s'mêêti se preveselo · êko že i prêe · doidêže prem'l'či · ${ }^{13} i$ v' 
tom' otrig'nu s(love)sa · Tako g(ospod)i aĉe hoĉeši biti s mnoju · i az's toboju • i nikoliže ot tebe ne otlučiti se ·

${ }^{14}$ Čtt(e)n(ie) · Rek'ši že ei sie Šendr' ruta žena č(a)stna pače pročihb služ'benicb ee čeladi tv'rdostan'no m(o)laše ju · da êvila bi ei s kêmb gl(agol)ala bi $\cdot{ }^{15} \mathrm{~B}(\mathrm{la})$ ž(e)na že Elizabêt' êko ne hoteĉi i uklanajuĉi se · i pros'bami ee premožena otveĉa · Vidêhь nebo otvr'sto - i onogo slat'kago $I$ (su)sa $H($ rbst)a g(ospod)a moego priklon'ša se k' mnê · i utêšajuĉa me ot vsêhь skr'bi moihь $\cdot$ i ot vsêhь tugь moihь eže obidu me ·

${ }^{16}$ Čt(enie) · Pristupi že idêže kralı ugr'ski o(tь)cь see Elizabêti · poslalı b(ê)še kneza imen(e)mь Paviê s mnoju družinoju · da prizval' bi deĉerb svoju v' z(e)mlju svoju •

${ }^{17}$ Slišal' bo bê da lêki pros'êkina vsakogo ugodiê ulišila se bi · i prišad' $k$ gradu

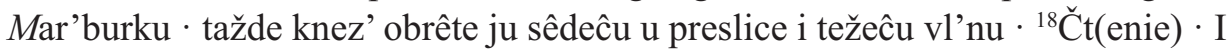
divleniê radi bl(agoslo)ve gl(agola)še · Nikoliže deĉi kraleva vidêna e(stb) vl'nu preducii $\cdot{ }^{19}$ siê vsakoêki ubož'stvo želêjuĉi i uničiženie ne može ju iz'ves'ti ${ }^{20} E g d a$ že posalı ot(ь)čь v z(e)mlju roistva svoego vzvrati se $\cdot{ }^{21}$ plaĉb ei plav' noseĉi $\cdot \mathrm{i}$ malo kratı drugoga lica suk'na imêše ·

${ }^{22}$ čt(enie) · I por'mnanie (sic!) stvori (sic!) gr'daê (sic!) rabina · i r(e)če eže slišala bê ot b(la)ž(e)nie Elizabêti · prêžde prestavleniê ee takoju gl(agol)juĉu · juže v'rême nastoitь · v neže v'semogi $B(\mathrm{og})$ ь têhь iže sutь priêt(e)li ego prizovetь . ${ }^{23} \mathrm{R}(\mathrm{e})$ če čto vsaki d(a)nь ' ona êže bliz' bê prestavleniem' ee prez'bož'na b(ê)še . ${ }^{24} I$ v' onь časb semr'ti lêki s'peĉi leža i iz' daše · ${ }^{25}$ čte(nie) · I egda četire d(ь)ni ot časa semr'ti · t(ê)lo b(la)ž(e)nie Elizabêti · nepogrebeno ležalo bê · nikoeže vone s'mrada ne imê $\cdot$ êkože običai e(stb) ot druzêhb ${ }^{26}$ na pače $\cdot$ ot nee telese is'hoêše bl(a)gouhanie aromati · eže vidêše se d(u)hь ukrêplajucii imêše $\cdot{ }^{27}$ oblêčeno že bê t(ê)lo ee sineju suk'neju · i lice ee suk'nom' ob'vezano $\cdot{ }^{27}$ mnozi b(o)ž(a)stviemb vžeženi lap'tace suk'na urêzovahu · a druzi nohat ee · ini že vlass ee ·

${ }^{28} \mathrm{v}$ si d(a)nь ničtože budi ot s(veta)go Ponciêna $\cdot$ na ini d(a)nь čtuet se $\cdot$

${ }^{1} \mathbf{d}(\mathbf{a}) \mathbf{n} \mathbf{b}$ ] om. Pm Vat ${ }_{19}$ Vinod Vat $_{10}$ Mavr Bar $\mid$ s(ve)tie ] s(ve)te Vat Pm Vat ${ }_{19}$ $\mathrm{N}_{1}$ Met Vinod Vat ${ }_{10} \mathrm{Lab}_{2}$ Mavr Hum Bar | Elizabêti ] Elisavti $\mathrm{Vb}_{4}$ Met Elizabeti Pm Vinod Vat ${ }_{10} E$ lizab(e)ti hĉere ugrsk(a)go krala Vat ${ }_{19}$ Elizabeti k'çerê kr(a)la ugr(skago) Mosk Elizabeti d(a)nь Lab $_{2}$ Elisav' Mavr Eliz(abêti) Bar | or(a)cii ] or(a)c(iê) Vat ${ }_{6}$ Lab $_{2}$ Mosk om. Vb Vat $_{19}$ Vinod Mavr orbciê $\mathrm{N}_{1}$

${ }^{2}$ Tvoihь ] praec. $\mathrm{B}(\mathrm{ož}) \mathrm{e} \mathrm{N}_{1} \mid$ sr(bd)ca ] sr'ca Vat ${ }_{19}$ Mosk $\mathrm{N}_{1}$ srca Bar | vêr'nihb ] vêrnihь Vat ${ }_{6} \mathrm{Pm}$ Vinod Vat ${ }_{10}$ Hum Bar ver'nihь Vat ${ }_{19} \mathrm{~N}_{1} \mathrm{Lab}_{2}$ vernihь Met b(ož)e ] om. $\left.\mathrm{N}_{1} \mid \mathbf{m}(\mathbf{i}) \mathbf{l}(\mathbf{o}) \mathbf{s r d} \mathbf{b}\right] \mathrm{m}(\mathrm{i}) 1(\mathrm{o})$ srdi Mosk Vat $\left.{ }_{10} \mid \operatorname{prosv}(\hat{\mathbf{e}}) \mathbf{t i}\right]$ prosvêtli $\mathrm{Vb}_{4}$ (marg.) Mosk Met Mavr Vat ${ }_{10}$ prosvetli $\mathrm{Lab}_{2} \mid \mathbf{i}$ b(la)ž(e)nie ] illeg. $\mathrm{Vb}_{4}$ (marg.) i bl(a)ž(e)ne Mavr | Elizabeti ] Elizabêti Vat ${ }_{6}$ Vat $_{19}$ Mosk $_{1}$ Hum illeg. Vb $_{4}$ (marg.) Elisavti Met Elisav'ti Mavr | pros'bami ] <..> $\mathrm{ami} \mathrm{Vb}_{4}$ (marg.) prosbami Pm 
Vat $_{19}$ Met Vat ${ }_{10}$ Hum proz'b(a)mi Mosk $\mathrm{N}_{1}$ Lab $_{2}$ prozbami Mavr Bar | sl(a)vnimi ] s'l(a)vnimi $\mathrm{N}_{1}$ slav'nimi $\mathrm{Lab}_{2} \mid$ stvori ] s'tvori $\mathrm{N}_{1} \mathrm{Hum} \mid \mathbf{n i}$ ] n(a)sb Vat ${ }_{6} \mathrm{~N}_{1} \mid$ za ljub(a)vb ] om. $\mathrm{Vb}_{4}$ (marg.) Pm Met Vat ${ }_{10}$ Mavr Bar | tvoju ] om. Pm Met Mavr Bar | mir'ska naslaždeniê ] naslajeniê mir $<\mathrm{s}>\mathrm{ka}$ Vat ${ }_{6}$ naslaženiê mir'skaê $\mathrm{Vb}_{4}$ (marg.) naslaždeniê mirska Pm naslaeniê Vat ${ }_{19}$ naslajeniê mir's'ka Mosk mir's'ka nas'laždeniê $\mathrm{N}_{1}$ naslaeniê mirska Met Vat ${ }_{10}$ naslaêniê mir'ska Lab ${ }_{2}$ naslaeniê mir'ska Met mir'ska nas'laždeniê Hum naslaeniê mirska Bar | nenavidêti ] nenaviditi Vat Vinod $\mathrm{Lab}_{2}$ Bar illeg. $\mathrm{Vb}_{4}$ (marg.) $\mid \mathbf{n}(\mathbf{e}) \mathbf{b}(\mathbf{e})$ skago dara pričeĉeniem' ] n(e)b(e)-

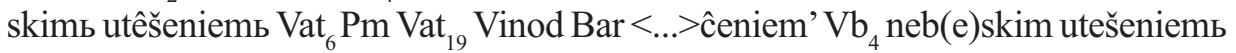
Mosk Vat ${ }_{10} \mathrm{n}(\mathrm{e}) \mathrm{b}(\mathrm{e})$ skimb utêžaniemb $\mathrm{N}_{1} \mathrm{n}(\mathrm{e}) \mathrm{b}(\mathrm{e})$ skimb utišeniemь Met nebeskimb utešeniemb $\mathrm{Lab}_{2} \mathrm{n}(\mathrm{e}) \mathrm{b}(\mathrm{e})$ skimb utešeniemb Mavr | vsgda ] vssgda Pm Met Vat ${ }_{10}$ Mavr v'sag'da Mosk $\mathrm{N}_{1}$ vs(a)gda Vinod v'sagda Hum vsag'da Bar $\mid$ g(ospode)mb ] om. Vat ${ }_{6} \operatorname{Vat}_{19}$ Mosk $\mathrm{N}_{1}$ Met Lab 2 Mavr Hum add. n(a)̌̌s(i)m(b) $\mathrm{Vb}_{4} \mathrm{Pm} \mathrm{Bar}$

3̌čten'ie ] om. $\mathrm{N}_{1}$ Lab $_{2}$ Mavr Bar $\mid$ Elizabêt' ] Elisavta $\mathrm{Vb}_{4}$ Met Mavr Elizabetb $\operatorname{Pm} N_{1}$ Vinod $L_{a b} \operatorname{Bar} \mid$ stoeĉi ] s'toeĉi $N_{1}$ Hum | ôce stoeĉi ] stoeĉi oĉe Met | v' oblačilê ] va oblačili Vat ${ }_{6}$ va oblačilê $\mathrm{Vb}_{4}$ Mosk $\mathrm{N}_{1}$ Met vb oblačili Pm Vat ${ }_{10}$ va ob'lačili $\mathrm{Lab}_{2}$ va oblačii Bar | mir'scêi ] praec. sl(a)vê Vat ${ }_{6} \mathrm{Vat}_{19}$ mirscêi $\mathrm{Vb}_{4}$ Met sl(a)vê mirscêi Pm Hum sl(a)vi mir'sbcêi Mosk s'lavê mirscêi $\mathrm{N}_{1}$ sl(a)vê mir'scê Vinod sl(a)vi mirskie Vat ${ }_{10}$ mir'scei $\mathrm{Lab}_{2}$ praec. sl(a)vi Mavr sl(a)vi mirscêi Bar | nemoĉ'na ] nemoĉna $\mathrm{Vat}_{6} \mathrm{Vb}_{4}$ Met Mavr | pros'êka ] prosêka Vat ${ }_{6}$ prosiêka $\mathrm{Vb}_{4}$ Vat $_{19}$ Met Mavr proêsika (sic!) Vat ${ }_{10} \mid$ g'nus'na zrakomb ] zrakomb gnusna Vat ${ }_{6}$ gnusna zrakomb $\mathrm{Vb}_{4} \mathrm{Pm}$ Vat ${ }_{19}$ Met Vat ${ }_{10}$ Mavr Hum Bar gnjusna zrakomb Vinod gnus'na zrakomb $\mathrm{Lab}_{2} \mid$ bolêz'niju ] bolizniju Vat 6 bolêzniju $\mathrm{Vb}_{4} \mathrm{Pm} \mathrm{N} \mathrm{N}_{1}$ Vinod Vat $_{10}$ Mavr Hum Bar bolezniju Met bolez'niju $\mathrm{Lab}_{2} \mid$ truždajuĉa se ] praec. i Vat ${ }_{6}$ truždajuci se Pm truêjuĉa se Mosk truêjuĉa se $\mathrm{N}_{1}$ Met Bar truždajuĉi se Vat ${ }_{10}$ truêjuĉ́' se Mavr | poêm'ši ] poim'ši $\mathrm{Vb}_{4}$ poêmši $\mathrm{Pm}$ Met Hum Bar priêm'ši $\mathrm{N}_{1}$ poemši Mavr | vlaĉima rukama svoima ] vlaĉeju rokoju svoeju Vat ${ }_{6} \mathrm{om}_{\text {. svoima }}$ $\mathrm{Vb}_{4}$ Pm Vat ${ }_{19}$ Vinod Vat ${ }_{10}$ Lab $_{2}$ Bar v'laciima rukama Mosk svoima rukama Met vlaĉima ruk'ma Mavr $\mid$ ostrigaše ] os'trigaše $\mathrm{N}_{1}$ Vat $_{10}$ Bar $\mid$ gnus'nie ] gnusnie Vat ${ }_{6}$ $\mathrm{Vb}_{4}$ Pm Vat ${ }_{19}$ Met Vat ${ }_{10}$ Bar g'nusbnie $\mathrm{N}_{1}$ gnjusnie Vinod g'nusnie Hum | vlasi ] v'lasi Mosk | k ] praec. i Vat ${ }_{6}$ i k' Mosk $\mathrm{Lab}_{2} \mathrm{k}^{\prime} \mathrm{N}_{1}$ Bar | nadrom' ] nedrom' $\mathrm{Vb}_{4}$ Pm Vat ${ }_{19} \mathrm{~N}_{1}$ Met Vat ${ }_{10}$ Mavr Hum nad'romb Mosk Lab ${ }_{2}$ Bar $\mid$ svoim' ] s'voemb Mosk | glavu ego priklon'ši ] prikon'ši gl(a)vu ego Vat ${ }_{6}$ gl(a)vu ego priklonši $\mathrm{Vb}_{4}$ Met Hum Bar add. Čte(nie) Pm glavu ego prek'loniv'ši Mosk gl(a)vu ego priklonivši $\mathrm{N}_{1}$ priklon'ši gl(a)vu ego Vat ${ }_{10}$ glavu ego prik'lonivaše $\left.\mathrm{Lab}_{2} \mid \mathbf{i}\right] \mathrm{i} \mathrm{Vb}_{4} \mid$ omi ] umi $\mathrm{Vat}_{6} \mathrm{Vb}_{4}$ Met Lab ${ }_{2} \mid \mathbf{v}^{\prime}$ vr'tê ] v vrti Vat ${ }_{6} \mathrm{v}$ vr'tê Pm v(ь) vr(ь)ti Mosk va vr'tê $\mathrm{N}_{1}$ v' vrtê Met v' vrte Vat ${ }_{10}$ va vrti Lab ${ }_{2}$ Bar v v'rti Hum | svoemb ] s'voemb Mosk $\mathrm{N}_{1}$ praec. i potomb omi gl(a)vu ego taino va vrti Vat ${ }_{10}$ / hoteĉi se ] hoteĉê se Vinod om. se Lab ${ }_{2}$ hoteĉ́' se Mavr | se skriti ] skriti se Vat ${ }_{19}$ se s'kriti Mosk Vat $_{10}$ se s'kriti $\mathrm{N}_{1} \mid$ zraka č (lovêčb)skago ] č(lovêč)skago zraka $\mathrm{Vb}_{4}$ add. čt(en)i(e) Mavr 
${ }^{4}$ bêše ] biše Vat ${ }_{6} V_{10}{ }_{10} L_{2} \mid$ deĉi ] h'ĉi Mavr dêci Hum | krala ] k'rala Mosk kr'la Mavr | ugr'skoga ] ugrsk(a)go Vat ${ }_{6}$ ugr'skago $\mathrm{Vb}_{4}$ ugarskago Pm ug(a)rsk(a)go Vat ${ }_{19}$ Vat $_{10}$ ugrskago čt(en)i(e) $\mathrm{N}_{1}$ ugrskago Met Bar ugar'skago Lab ${ }_{2}$ ugr'sk'go Mavr ugarskoga Hum $\mid$ im(e)nemb $]$ om. $\mathrm{Vb}_{4} \mathrm{Pm}$ Met Vat ${ }_{10}$ Bar $\mid$ An'drêê ] Andriê $V_{\text {Vat }} \mathrm{om}$. $\mathrm{Vb}_{4} \mathrm{Pm}$ Met Vat ${ }_{10}$ Bar Andrêê Vat ${ }_{19} \mathrm{Lab}_{2}$ Hum An'dr'êê Mosk | na ] om. $\mathrm{Vat}_{6} \mathrm{nb} \mathrm{Vb}_{4} \mid$ premoĉ'na ] premoĉna $\mathrm{Vat}_{6} \mathrm{~N}_{1}$ Met Mavr Hum Bar prêmoĉna $\mathrm{Vb}_{4} \mid$ plemenita ] plêmenita $\mathrm{N}_{1} \mathrm{Hum} \mid$ lan'grata ] praec. vladiki Vat ${ }_{6}$ praec. vladatela $\mathrm{Vb}_{4}$ Pm Mosk Vat ${ }_{10} \mathrm{Lab}_{2}$ Hum vladat(e)la langrataVat ${ }_{19} \mathrm{~N}_{1}$ Bar vladatela langrada Met vlada $<$ te $>$ la langrata Vinod vladat(e)la lan' gr(a)da Mavr $\mid$ prin'čipa ] prinčipa $\mathrm{Vb}_{4}$ Met Vinod Hum Bar prin'cipa Vat ${ }_{19}$ principa $\mathrm{N}_{1} \mid$ paladina ] palatina $\mathrm{N}_{1} \mathrm{Vat}_{10} \mathrm{Lab}_{2}$

${ }^{5}$ Togo radi ] Tagda Mosk $\mathrm{Lab}_{2}$ om. radi Vinod Togo r'di Mavr | prišad'še ] prišadše $\mathrm{Vat}_{6} \mathrm{Vb}_{4} \mathrm{Vat}_{19}$ Met prišad'či $\mathrm{N}_{1}$ priš'd'še Mavr | rabi ] rabe $\mathrm{Lab}_{2} \mathrm{r}$ 'bi Mavr | ee ] ego Met | smêêše se ] smiêše se Vat ${ }_{6}$ Met Vat $_{10}$ Lab $_{2}$ Bar s'miêše se Mosk s'mêêše se $\mathrm{N}_{1}$ smêše se Vinod

${ }^{6}$ Čten(ie) ] om. Vat ${ }_{6} \mathrm{Vb}_{4} \mathrm{~N}_{1}$ Vinod Lab ${ }_{2}$ Mavr Bar praec. Ti že Pm Hum | B(la)ž(e)na ] Bl(a)ž(e)naê $\mathrm{N}_{1} \mid$ Elizabêt' ] Elisavta $\mathrm{Vb}_{4}$ Met Elizabetb Mosk Vinod Vat $\mathrm{Lab}_{2}$ Bar om. $\mathrm{N}_{1}$ Elisav'ta Mavr | često ] čisto $\mathrm{Vb}_{4}$ čes'to Vat ${ }_{19}$ Mosk $\mathrm{Lab}_{2} \mid \mathbf{v}^{\prime}$ noĉi ] v noĉi Vat ${ }_{6} \mathrm{Vb}_{4} \mathrm{Pm}$ Met Vinod $\mathrm{Lab}_{2}$ Mavr Bar om. $\mathrm{N}_{1} \mid$ na ] n' Mavr $\mid$ v' noĉi na m(o)I(i)tvu ] na molit'vu v' noĉi Vat ${ }_{10} \mid$ v'staêše ] vstaêše $V_{a t}{ }_{6} V_{6}$ Pm Met Vinod Vat $_{10}$ Lab $_{2}$ Mavr v's'taêše Mosk staêše $N_{1}$ ustaêše Bar | stužal' se bi ] vstužal bi se $V_{\text {Vat }}$ stužal se bi $\mathrm{Vb}_{4}$ Met Vinod Bar stužal se bi čt(en)i(e) Mavr add. čt(en)i(e) $\mathrm{N}_{1}$

${ }^{7}$ egda ] eda Met eg'da Vat ${ }_{10}$ eg'da Bar $\mid \mathbf{v}^{\prime}$ ] v Vat ${ }_{6} \mathrm{Vb}_{4}$ Met Vinod Vat ${ }_{10} \mathrm{Lab}_{2}$ Bar | svoei ] s'voei Mosk add. ruci Vat ${ }_{10}$ Bar $\mid$ dr'žaše ] držaše Vat ${ }_{6}$ Pm Vat $_{19}$ Met Vinod Vat ${ }_{10}$ Lab $_{2}$ Hum držašes $\mathrm{N}_{1}$ d'ržaše Bar $\mid$ eliko ] preac. i $\mathrm{N}_{1} \mid$ dl'go ] dlgo Met $\mathrm{Lab}_{2}$ Bar d'lgo Hum | m(o)laše ] mol'še Mavr | m(o)le ] m(o)l(a)še Bar | vratiti se ] vrati se $\mathrm{N}_{1} \mid$ ot š'kodi ] i ot škodi Vat ${ }_{6}$ ot škode $\mathrm{Pm} \mathrm{N}_{1} \mathrm{Lab}_{2}$ Bar ot škodi Vat ${ }_{19}$ Met Vinod Mavr Hum ot š'kode $\operatorname{Vat}_{10} \mid$ ee ] ego $\mathrm{Vb}_{4}$ Met Vat $_{10}$ Mavr Bar | pečalan' ] add. bê Vat ${ }_{6}$ pečalnь $\mathrm{Vb}_{4}$ add. čt(enie) Pm pečal'nь Mavr

${ }^{8}$ Elizabêt' $]$ Elizabitb Vat ${ }_{6}$ Elisavta $\mathrm{Vb}_{4}$ Met Mavr Elizabetb $\mathrm{N}_{1}$ Vinod Vat ${ }_{10}$ Lab $_{2}$ | pače ] p'če Pm Mavr om. Vat ${ }_{19} \mid$ čeĉe ] češ'če $\mathrm{N}_{1} V_{10}{ }_{10} \mid \mathbf{m}(\mathbf{o})$ li ] molaše Vinod | službenice ] add. svoe Vat ${ }_{6}$ služab'nice Vat ${ }_{19} \mathrm{~N}_{1}$ s'lužab'nice Mosk službenicê svoe Vat ${ }_{10}$ služьbenice $\mathrm{Lab}_{2} \mid$ eže ] ke Met Mavr $\mid$ neju ] nju Vat ${ }_{6} \mathrm{~N}_{1}$ nu Vat ${ }_{10} \mathrm{Lab}_{2}$ Bar | hoêhu ] hoždahu $\mathrm{Vb}_{4}$ Pm Vinod Lab ${ }_{2}$ hoĵahu Hum | noĉiju ] v noĉi Vat ${ }_{6} \mid \mathbf{k}^{\prime}$

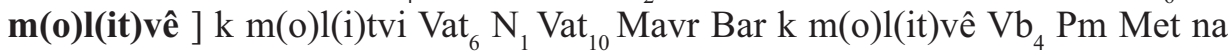
$\mathrm{m}(\mathrm{o})$ litvu Vat ${ }_{19}$ om. Mosk Lab ${ }_{2} \mathrm{nb} \mathrm{m}(\mathrm{o}) 1(\mathrm{i})$ tvu Vinod k’ m(o)l(i)tvi Hum | vzbûale bi ] vzbudili bi Vat ${ }_{6}$ vzbuždali bi $\mathrm{Vb}_{4}$ Pm Lab ${ }_{2}$ 'zbuêle bi Vat ${ }_{19}$ v'zbuêlê bi Mosk vz'b'uždale bi čt(en)i(e) $\mathrm{N}_{1}$ vzbuêli bi Met Mavr Bar v'zbuždale bi Vinod v'zbuêli 


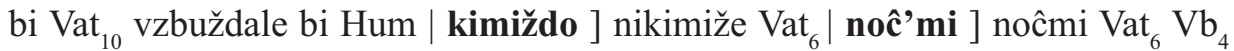
Pm Met Vinod Bar | obikati ] obikaše Vat ${ }_{6}$ Vat $_{19}$ Mosk Vat $_{10}$ Lab $_{2}$ Bar | v'staêše ] vstaêti Vat ${ }_{6}$ Vinod $V_{a t}{ }_{10} L_{2}{\text { vstaêše } \mathrm{Vb}_{4}} \mathrm{Pm} \mathrm{N} \mathrm{N}_{1}$ Met Mavr Hum Bar vstaêti čt(en)i(e) Vat ${ }_{19}$ v'staêti Mosk | gda ] kada Vat ${ }_{6} \mathrm{Vb}_{4}$ Pm N$_{1}$ Vinod Vat ${ }_{10}$ Mavr Bar I k(a)da Vat ${ }_{19}$ Mosk Lab ${ }_{2}$ kbda Met g'da Hum | muž ] mužb Vat ${ }_{6} V_{4}$ Pm om. Mosk $\mathrm{Lab}_{2} \mid$ ee ] om. Mosk Lab $\mid$ s'pal' bi ] spals bi $\mathrm{Vat}_{6} \mathrm{Vb}_{4}$ PmVat $_{10}$ Mavr om. Mosk Lab $_{2}$ s'paše $\mathrm{N}_{1}$ spal bi Met Vinod sspal bi Bar $\mid$ mogla se bi ] i kada ljubo mogla bi Vat ${ }_{6}$ kada ljubo mogla se bi $\mathrm{Vb}_{4}$ kada ljubo mogla bi Pm Vat ${ }_{19}$ Vinod Vat ${ }_{10}$ Bar mogla bi Mosk egda mogla bi $\mathrm{N}_{1}$ kbda ljubo mogla se bi Met mog'la bi Lab ${ }_{2}$ 'da ljubo mogla bi Mavr | iz'neti ] izneti se $\mathrm{Vat}_{6} \mathrm{Vb}_{4} \mathrm{Pm} \mathrm{Vat}_{19}$ Met Bar moliti se Mosk Lab $_{2}$ iz'neti se $\mathrm{N}_{1}$ Vinod Vat ${ }_{10}$ Mavr praec. g'da ljubo Hum izneti Hum

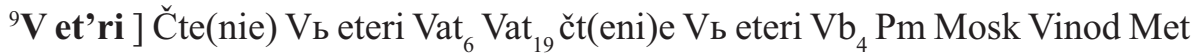
$\mathrm{Lab}_{2} \mathrm{~V}^{\prime}$ etiri $\mathrm{N}_{1}$ čten $<$ ie $>$ V eteri Vat ${ }_{10} \mathrm{~V}$ eteri Mavr Hum Ti že vb eteri Bar $\mid \mathbf{v}^{\prime}$ koriz'mi ] v kozimi (sic!) Vat ${ }_{6} \mathrm{v}$ korêrizmê (sic!) $\mathrm{Vb}_{4} \mathrm{v}$ korizmê Pm Met om. Vat ${ }_{19}$ v koriz'mi Vinod Vat ${ }_{10}$ Lab $_{2}$ Mavr vb korizmi Hum v korizmi Bar | preklon'ši ] preklonši Vat ${ }_{6} \mathrm{Vb}_{4}$ Met Bar prêklonši Pm $\mathrm{N}_{1}$ prêk'lon'ši Vat ${ }_{19}$ prek'lon'ši Mosk priklon'ši $\mathrm{Lab}_{2}$ priklonši Hum | kolêna ] kolina Vat ${ }_{6}$ kolenê Vat $_{19} \mathrm{~N}_{1}$ Met Bar kolêni Vinod Bar koleni $\operatorname{Vat}_{10}$ Lab $_{2}$ kol(ê)nê Mavr kolêne Hum | pri stêni ] pri stenê $\mathrm{Vb}_{4}$ Mosk $\mathrm{N}_{1}$ Met Mavr pri stênê Pm Vinod Hum v' koriz'mê pri s'tenê Vat ${ }_{19}$ pri steni $\operatorname{Vat}_{10} \mathrm{Lab}_{2} \mathrm{Bar} \mid$ pres'bož'ne ] prezbožna Vat ${ }_{6}$ prêsbožna $\mathrm{Vb}_{4}$ prizbožnê Pm prezbožnê Vat ${ }_{19}$ Bar prez'božno Mosk Lab ${ }_{2}$ prez'božnê $N_{1}$ prezbožno Met prez'božne Vinod prez'bož'nê Vat ${ }_{10}$ presbožno Mavr presbožnê Hum | oči ] očê Vat $_{19} \mid$ vpr'tê ] vprti Vat ${ }_{6}$ Mosk Met Lab vprtê Vat $_{19}$ Mavr v'prtê $N_{1}$ Hum v'prt'ê Vinod v'prti Vat ${ }_{10}$ Bar $\mid$ k' ol'taru ] ka oltaru Vat ${ }_{6}$ Met Vat ${ }_{10}$ Bar ka ol'taru Vb $_{4}$ Vat $_{19}$ kb oltaru Pm Vinod Hum ko oltaru $N_{1}$ k oltaru Lab ${ }_{2}$

${ }^{10}$ Čte(nie) ] om. Vat $\mathrm{Vb}_{4}$ Pm Vat ${ }_{19}$ Mosk Met Vinod Vat ${ }_{10}$ Lab $_{2}$ Mavr Bar praec. T(i) že Hum | I ] Ï $\mathrm{Vb}_{4} \mid$ Egda ] kada $\mathrm{N}_{1}$ k'da Mavr eg'da Bar $\mid$ v'rati se ] vrati se $\mathrm{Vb}_{4}$ Mosk Met Vinod Vat ${ }_{10}$ Lab $_{2}$ Mavr Bar $\left.\mid \mathbf{k}^{\prime}\right]_{\mathrm{k} \mathrm{Vb}}$ Met Vat ${ }_{10}$ Mavr Bar smêrenomu ] smêrenumu Mosk sımerenomu $\mathrm{N}_{1}$ smirenomu Met smerênomu Vat ${ }_{10}$

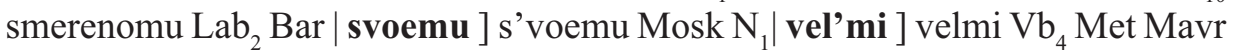
Hum Bar velm'i Vat ${ }_{19}$ | slaba ] s'laba Hum | vel'mi slaba bê ] slaba bê velmi Pm

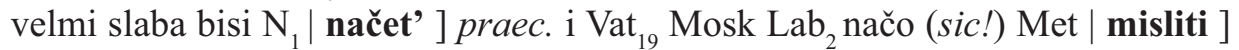
mis'liti Mosk mislitb Met moliti $\mathrm{Lab}_{2} \mid \mathbf{i}$ ] om. $\mathrm{N}_{1} \mid$ nasloni se ] om. Vat ${ }_{19}$ naslon' se $\mathrm{N}_{1} \mid$ na stênu ] na stenu Mosk Met Vat ${ }_{10}$ Lab $_{2}$ Bar na s'tenu $\mathrm{N}_{1}$ n' stenu Mavr | i ] om. Met | pod'êta ] podêta $\mathrm{Vb}_{4} \mid$ bê ] b(i)si Vat ${ }_{19}$ om. Vat $_{10} \mid$ Sen'drudinomb ] Sindrutinimb Vat ${ }_{6}$ Sin'drudinim' Vb $_{4}$ Mavr Sindrundine Pm Šen'drutinim' Vat ${ }_{19}$ Sindrudimь Mosk Sinad'runimь $\mathrm{N}_{1}$ Sindrudinimь Met Senadrud'nimь Vat ${ }_{10}$ Sin'drudinomь $\mathrm{Lab}_{2}$ Sendrudinimь Bar 
${ }^{11}$ Vse ] add. že Vat ${ }_{6} \mathrm{Vb}_{4}$ Pm Met Vinod Lab 2 Mavr V'se že Vat ${ }_{19}$ Mosk Vat ${ }_{10}$ Bar | iz'gnav'ši ] izagnavši kada ljubo m(u)žb ee spal' bi Vat ${ }_{6}$ izgnavši $\mathrm{Vb}_{4}$ Hum Bar izgnav'ši Pm izagnav'ši kada ljubo mužs ee spal' bi Mosk izig'nav'ši da kada m(u)žь ee s'pal' bi čt(en)i(e) $\mathrm{N}_{1}$ izьgnavši Met izagnav'ši Vinod Vat ${ }_{10}$ izagnav'ši kada ljubo m(u)žb ee spal' bi Lab 2 iz'gnavši Mavr | t'kmo ] takmo Vat ${ }_{6} \mathrm{Vb}_{4}$ Met $\mathrm{Vat}_{10}$ Hum Bar tak'mo $\mathrm{N}_{1} \mathrm{Lab}_{2}$ t'kmo Mavr $\mid$ malo ] mal'o Lab L $_{2} \mid$ rabb ] r'bь Mavr

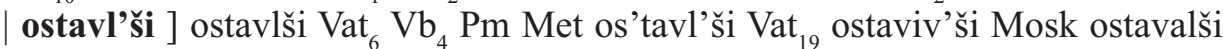
Vinod Lab Bar ostaval'ši Vat $_{10}$ Hum | s' soboju ] sa soboju Vat ${ }_{6}$ Mosk Vat ${ }_{10}$ Lab $_{2}$ Bar sь soboju $\mathrm{Vb}_{4} \mid$ oči ] očê Vat ${ }_{19} \mid \mathbf{v}^{\prime}$ prtê ] vprti Vat ${ }_{6} \mathrm{Lab}_{2}$ vprtê $\mathrm{Vb}_{4} \mathrm{Pm}$ Met Mavr v'prti Mosk Vat ${ }_{10}$ Bar vp'rtê Vinod v'prtê Hum | k ponêstrê otvr'stê obraĉenê ] obraceeni k ponêstrê otvrstoi Vat ${ }_{6}$ obraĉenê k' ponestrê otvr'stvê $\mathrm{Vb}_{4}$ obracenê $\mathrm{k}$ ponêstrê otvrstê $\mathrm{Pm}$ i ob'raceenê k' pones'trê otvrs'tê Vat ${ }_{19} \mathrm{ob}^{\prime}$ 'raĉeni k' ponêstrê otvrstêi Mosk obraceenê k' ponêstrê otvr'stê $\mathrm{N}_{1} \mathrm{k}$ ponestrê otvrstê Met i obraceenê k ponêstrê otvrstê Vinod obraĉeni k' ponêstri otvrsti Vat ${ }_{10}$ obraceeni k ponestri otvrsti Lab ${ }_{2}$ obraĉenê k ponestrê otvr'stê Mavr k ponestrê otvrstê obraĉene Hum obraĉeni k fonestri otvrsti Bar $\mid$ smêêti se ] smiêti se Vat ${ }_{6}$ Met Vinod Vat ${ }_{10} \mathrm{Lab}_{2}$ Bar s'mêêti se Vat ${ }_{19} \mathrm{~N}_{1} \mathrm{Lab}_{2}$ smeêti se Mavr $\mid \mathbf{i}$ ] om. Vat $\mathrm{Vb}_{4}$ Pm Vat ${ }_{19} \mathrm{~N}_{1}$ Met Vinod $\mathrm{Vat}_{10} \mathrm{Lab}_{2} \mathrm{Bar} \mid$ preslat'ko ] preslatko $\mathrm{Vb}_{4}$ Met prêslatko Pm pres'lat'ko Mosk

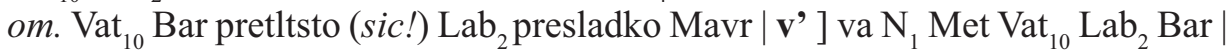
velicê ] om. Pm Met velici Mosk Vinod Vat ${ }_{10} \mathrm{Lab}_{2}$ Bar v(e)lici $\mathrm{N}_{1} \mid$ vesel'i ] veseli Vat $_{6} \mathrm{Pm}$ veselii $\mathrm{Vb}_{4}$ Met $\mathrm{Lab}_{2}$ Mavr vesel'ii Vinod veseliji Vat ${ }_{10}$ Bar

${ }^{12}$ Čten(ie) ] om. Vat ${ }_{19}$ Lab $_{2}$ Mavr praec. Ti že Vat ${ }_{10}$ Ti že Bar $\mid$ m'nozê že časê ] mnozi že časi Vat ${ }_{6}$ Vat $_{10}$ Bar mnozê že časê $\mathrm{Vb}_{4} \mathrm{Pm} \mathrm{Vat}_{19}$ Vinod Mavr Hum mnozi že časê Mosk mnozi že vrimeni časa Met m'nozi že časi $\mathrm{Lab}_{2} \mid$ zatvori ] zat'vori $\mathrm{N}_{1} \mid$ oči ] add. s'voi Mosk $\mathrm{N}_{1} \mid \mathbf{i}$ ] om. Vat $_{6} \mathrm{Vb}_{4}$ Met Mavr | ispusti ] ispus'ti Vat ${ }_{19}$ is'pusti očima $\mathrm{N}_{1} \mid$ sl'zi ] slzi Vat ${ }_{6}$ Mosk $\mathrm{N}_{1}$ Met Vinod Lab ${ }_{2}$ Mavr Hum Bar add. čt(en)i(e) Vat ${ }_{19}$ suzi Vat $_{10} \mid$ potom' ] praec. i Vat ${ }_{19}$ Vinod $\mid$ pomalu ] i pomalê Vat Pm $\mathrm{N}_{1}$ i pomalo $\mathrm{Vb}_{4}$ praec. i Mosk $\mathrm{Vat}_{10} \mathrm{Lab}_{2}$ Mavr Bar pomalê Vinod | i opet' ] I paki $\mathrm{Vb}_{4} \mathrm{Vat}_{19}$ Vinod praec. čt(en)i(e) Mavr | počet' ] pače Vat ${ }_{6}$ poče Pm Vat ${ }_{19}$ Mosk Met Vat ${ }_{10}$ Lab $_{2}$ Mavr Bar nače $\mathrm{N}_{1} \mid$ s'mêêti se ] smiêti se Vat ${ }_{6}$ Met Vinod Vat $_{10}$ Bar smêêti se $\mathrm{Vb}_{4}$ Pm Vat ${ }_{19}$ Mavr s'miêti se Mosk s'miêti se $\mathrm{N}_{1} \mid$ preveselo ] preveliko Mosk prevesêlo Vat ${ }_{10} \mid$ prêe ] prêžde $\operatorname{Vat}_{6} \mathrm{Vb}_{4} \mathrm{Pm} \mathrm{N}_{1}$ Vinod prije Mosk prie Met Lab ${ }_{2}$ Hum Bar priê Vat ${ }_{10}$ pree Mavr | doidêže ] doideže $\mathrm{Vb}_{4} \mathrm{~N}_{1}$ Vinod $\mathrm{Lab}_{2}$ Bar dondêže Pm Mavr dondeže Vat $_{19}$ dondiže Met $\mid$ prem'l'či ] premlča $V_{\text {Vat }}$ Pm Mosk Met Lab 2 Mavr Bar prêml'ča $\mathrm{Vb}_{4}$ Vat $_{19} \mathrm{~N}_{1}$ preml'ča Vinod Hum premuča Vat $_{10}$

${ }^{13} \mathbf{v}^{\prime}$ ] v Vb${ }_{4}$ Vat $_{19} \mathrm{~N}_{1}$ Met Vinod Vat ${ }_{10}$ Mavr Hum Bar | otrig'nu ] otrignu $\mathrm{Vb}_{4}$ Met Vinod Vat ${ }_{10}$ Mavr Hum Bar | i v' tom' otrig'nu s(love)sa· ] om. Vat ${ }_{6} \mathrm{Pm} \mid$ Tako g(ospod)i acee ] Tak $<$.. $>$ ti Vat ${ }_{6}$ Tako g(ospod)i ti $\mathrm{Vb}_{4}$ Pm Mosk Met Mavr 
Tako g(ospod)i ace ti Vinod tako g(ospod)i ako ti Vat ${ }_{10}$ Tako g(ospod)i ace ti hoĉeši Lab ${ }_{2} t(a) k o g(o s p o d) i$ ako ti hoĉeši Bar $\mid$ hoĉeši ] hoĉešb Mavr $\mid$ g(ospod)i aĉe hoĉeši ] hoĉeši $g\left(\right.$ ospod)i $\mathrm{N}_{1} \mid$ biti ] sa mnoju Mosk sa m'noju Lab $\mathrm{s}$ ' mnoju Mavr $\mid$ s mnoju ] sa mnoju Vat ${ }_{6} \mathrm{Vb}_{4} \mathrm{~N}_{1}$ Hum Bar sь mnoju Pm Vat ${ }_{19}$ Met Vinod biti Mosk Lab ${ }_{2}$ sa m'noju Vat ${ }_{10} \mid \mathbf{a z}^{\prime}$ ] a $<$ zb $>$ Mavr $\mid$ ot tebe ne otlučiti se ] ne hoĉu se otlučiti ot $\mathrm{t}(\mathrm{e})$ be Vat ${ }_{6}$ Pm Mosk $\mathrm{Lab}_{2}$ ne hoĉu se otlučiti ot $\mathrm{t}(\mathrm{e})$ be Ti že g(ospod)i $\mathrm{Vb}_{4}$ ne hoĉu otlučiti se ot tebe Vat ${ }_{19}$ Vinod Hum hoĉu ot tebe otlučiti se $\mathrm{N}_{1}$ ne hoĉju se otlučiti ot tebe Met ne hoĉu nikoliže otlučiti se ot tebê Bar | nikoliže ot tebe ne otlučiti se ] ne hoĉu nikoliže od'lučiti se ot tebe Vat ${ }_{10}$ nikoliže ne hoĉu otlučiti ot $\mathrm{t}(\mathrm{e})$ be Mavr

${ }^{14}$ Čt(e)n(ie) ] om. Pm Vat ${ }_{19}$ Mosk Lab ${ }_{2}$ Mavr $\mid$ Rek'ši ] Rekši Vat ${ }_{6} V_{b_{4}}$ Pm Met $\mathrm{N}_{1}$ Mavr Hum Bar Reč' Mosk Vat ${ }_{10} \mathrm{R}(\mathrm{e}) \mathrm{če}^{\mathrm{Lab}}{ }_{2} \mid$ ei ] om. Mosk $\mid$ Šendr'ruta ]

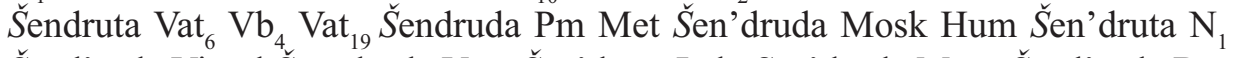
Šend'ruda Vinod Šenadruda Vat ${ }_{10} S$ en'druta $\mathrm{Lab}_{2} S$ en'druda Mavr $\breve{S}$ end'ruda Bar | ̌́(a)stna ] čsstna $\mathrm{Vb}_{4}$ Mavr Hum čsst'na Vat ${ }_{19}$ čast'na $\mathrm{N}_{1} V_{\text {Vat }}{ }_{10}$ Lab $_{2}$ čsst'na Vinod | pače ] рьс̌e $\mathrm{Vb}_{4}$ Mavr | služ'benics ] službenicь Vat ${ }_{6}$ Pm Met Vinod Mavr Hum Bar služabnicь Vat ${ }_{19}$ s'lužabnicь Mosk služab'nicь $\mathrm{N}_{1}$ Vat $_{10}$ službenica Lab ${ }_{2}$ | tv'rdostan'no ] tvrdostanno Vat ${ }_{6}$ Met Bar tvr'dostanno Pm tvrdost'n'no Vat ${ }_{19}$ tv'rdos'tan'no Mosk tvrdostan'no Vinod Lab 2 Mavr tvrdost(a)no Vat ${ }_{10}$ 'tvrdostanno Hum | m(o)laše ] mol'še Mavr | êvila bi ] êvil' bi Mavr | ei ] nei Vat ${ }_{19}$ ee Vinod | $\mathbf{s}$ kêmь ] s kimь Vat ${ }_{6} \mathrm{Pm} \mathrm{Vat}_{19}{\text { Mosk } \mathrm{N}_{1} \text { Vinod Vat }}_{10} \mathrm{Lab}_{2}$ Mavr Hum Bar $\mid$ gl(agol)ala bi ] gla(gola)la bê $\mathrm{Vb}_{4} \mathrm{~N}_{1}$ add. čt(en)i(e) Vat ${ }_{19}$ govoril' bi čt(en)i(e) Mavr

${ }^{15}$ že ] om. Vb $_{4}$ Mosk N 1 Met Vat ${ }_{10}$ Mavr Bar | Elizabêt'] Elisav'ta Vb 4 Elizabetb Mosk $\mathrm{N}_{1}$ Vinod Vat ${ }_{10}$ Lab $_{2}$ Bar Elisavta Met Elis'v'ta Mavr $\mid$ hoteĉi ] hotejuĉi Pm | uklanajuĉi se ] uk'lanajuci se Vat ${ }_{19}$ Mosk Lab ${ }_{2}$ klanajuĉi se Vinod | pros'bami ] prosbami Vat ${ }_{6} \mathrm{Pm}$ Met Hum prozbami $\mathrm{Vb}_{4} \mathrm{~N}_{1}$ Mavr Bar proz'bami Mosk Vat ${ }_{10}$ $\mathrm{Lab}_{2} \mid$ premožena ] add. bê Vat ${ }_{6}$ prêmožena $\mathrm{N}_{1} \mid$ otvecea ] otvêĉa Vinod | Vidêhb

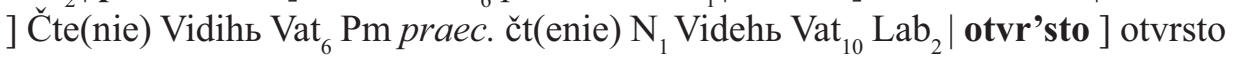
Vat $_{6}$ Pm Met Vinod Vat ${ }_{10}$ Mavr Hum Bar otvrs'to Mosk Lab ${ }_{2} \mid$ onogo ] onoga Mavr | slat'kago ] slatkago Vat ${ }_{6} \mathrm{Vb}_{4}$ Pm Met Hum Bar s'latk(a)go Mosk slad'koga Mavr | I(su)sa ] za (sic!) Vat ${ }_{6} \mid \boldsymbol{I}$ (su)sa $\boldsymbol{H}$ (rbst)a ] Is(u)h(rbst)a Vat ${ }_{19}$ Vat $_{10} \mathrm{Lab}_{2}$ $\operatorname{Bar} \mid \mathbf{g}\left(\right.$ ospod)a ] om. Mosk | priklon'ša se ] i priklonše se Vat ${ }_{6}$ prêklon'ša se $\mathrm{Vb}_{4}$ prêklonša se Pm prik'lon'ša se Mosk prêklonьša se $\mathrm{N}_{1}$ preklonša se Met Mavr priklonša Vinod prik'lonša se $\mathrm{Lab}_{2}$ priklonša se Bar $\mid \mathbf{k}^{\prime}$ ] $\mathrm{ka} \mathrm{Vb}_{4}$ Vat $_{19}$ Mosk $\mathrm{N}_{1}$ $\operatorname{Vat}_{10} \operatorname{Lab}_{2}$ Bar | mnê ] m'nê Vat ${ }_{19}$ Mosk $\mathrm{N}_{1}$ Vinod Vat ${ }_{10}$ Lab $_{2}$ mni Met | utêšajuĉa me ] utêšajuĉago me Vat ${ }_{6} \mathrm{Pm} \mathrm{Vat}_{19}$ jutêšajuĉa me $\mathrm{Vb}_{4}$ utešavajuĉ(a)go me Mosk utêšajuĉ' me $\mathrm{N}_{1}$ Mavr utišavajuĉa me Met utêšajuĉago Vinod utešajuĉa me Vat ${ }_{10}$ utešajuĉago me $\mathrm{Lab}_{2} \mid$ ot vsêhb skr'bi moihb i ot vsêhb tugb moihь ] ot vsêhb tugb $i$ ot vsêhb skrbs moihь $V_{6} \mathrm{Vb}_{4} \mathrm{~N}_{1}$ Mavr ot vsêhь tugb i ot vs(ê)hь skrbi 
moihь Pm Vinod Vat ${ }_{10}$ Bar ot vs(ê)hь skrbь i tugь moihь Vat ${ }_{19}$ ot v'sêh tugь i skr'bь moihь Mosk ot vsihь tugь i ot vsihь skrbь moihь Met ot vsehь tugь i oda v'sehь skrbi moihь Lab ${ }_{2}$ ot vs(ê)hь skrbь moih' i ot vs(ê)hь tugь moihь Hum | eže ] iže $\mathrm{Vb}_{4}$ ke Mavr $\mid$ obidu ] boid(u) (sic!) Bar

${ }^{16}$ Čt(e)nie ] om. Vat ${ }_{6} \mathrm{Pm} \mathrm{N} \mathrm{N}_{1}$ Met Lab ${ }_{2}$ Mavr | idêže ] idiže Met ideže Vat ${ }_{10}$ $\mathrm{Lab}_{2}$ Bar $\mid$ kralb ] kral Vat ${ }_{10} \mid$ ugr'ski ] ugrski Vat ${ }_{6}$ Mosk Met Vinod Vat ${ }_{10} \mathrm{Lab}_{2}$ Bar ugar'ski Pm ugarıs'ki Vat ${ }_{19}$ ugarski $\mathrm{N}_{1}$ Hum | see ] sie Vat ${ }_{6}$ ee $\mathrm{N}_{1} \mid$ Elizabêti ] Elisav'ti $\mathrm{Vb}_{4}$ praec. k' $\mathrm{N}_{1}$ Elisavti Met Mavr Elizabeti Vinod Vat ${ }_{10} \mathrm{Lab}_{2}$ Bar b(ê)še ] biše Vat ${ }_{6}$ Mosk Vat ${ }_{10} \mathrm{Lab}_{2} \mid$ kneza ] k'neza Mosk $\mathrm{N}_{1}$ knêza Vat ${ }_{10} \mid$ imen(e)mb ] imenêmb $V_{a t} \mid$ Paviê ] Pavoê Mosk $P$ 'viê Mavr $\mid$ s mnoju ] sa mnoju Vat ${ }_{6}$ s mnogoju $\mathrm{Vb}_{4}$ Vat $_{19}$ Met Vinod Vat ${ }_{10}$ sь mnogoju Pm Mosk $\mathrm{N}_{1}$ Mavr Hum Bar sa m'nogoju $\mathrm{Lab}_{2} \mid$ družinoju ] d'ružinoju Vat ${ }_{19}$ Mosk | prizval' bi ] prizval bi Pm Met Vinod Lab 2 Mavr Bar priz'val bi Mosk Hum priz'val' bi Vat ${ }_{10} \mid$ deĉerı ] dêcerı Vat ${ }_{10}$ Hum hêerb Mavr | svoju ] s'voju Vat ${ }_{19}$ Mosk | v' ] v Vat ${ }_{6} \mathrm{Pm} \mathrm{N}_{1}$ Met Vinod Vat ${ }_{10} \mathrm{Lab}_{2}$ Hum Bar $\mid$ svoju ] finis Pm s'voju Vat ${ }_{19}$ Mosk s'voju finis $\mathrm{N}_{1}$

${ }^{17}$ Slišal' ] s'lišal Mosk slišal Met Vinod Hum Bar praec. čt(enie) Mavr | bê ] bi Mosk biše $\mathrm{Lab}_{2} \mid$ da $]$ om. $\mathrm{Lab}_{2} \mid$ lêki ] leki Mosk $\mathrm{Lab}_{2} \mid$ pros'êkina ] prosêina Vat ${ }_{6}$ prosêkina $\mathrm{Vb}_{4}$ prosiêkina Met Mavr | vsakogo ] v'sak(o)go Mosk vsьkogo Met Mavr | ugodiê ] ogodiê $\mathrm{Vb}_{4} \mid$ ulišila se bi ] ulišila se bê čt(en)i(e) Vat ${ }_{19}$ lišila se bê Met lišila se bi Vat ${ }_{10}$ Bar ulišili se bi Lab ${ }_{2}$ ulišil' se bi Mavr ulišila se bê Hum | prišad' ] priš'd' Mavr | k gradu ] k' gradu Vb ${ }_{4} V_{a t}{ }_{19}$ Vinod ka gradu Mosk Vat ${ }_{10}$ $\mathrm{Lab}_{2} \mid$ Mar'burku ] Mar'burbku $\mathrm{Vb}_{4} \mathrm{Lab}_{2}$ Marburku Vat ${ }_{19}$ Met Vinod Mavr Hum Bar Bar'bur'ku (sic!) Mosk | tažde] taž' de Mosk tae Met Vat ${ }_{10}$ Mavr Bar | knez' ] k'nezb Mosk om. $\mathrm{Lab}_{2} \mid$ obrête ] obrite Vat ${ }_{6}$ Met obrete $\operatorname{Vat}_{10} \mathrm{Lab}_{2} \mathrm{Bar} \mid$ sêdeĉu ] sideĉu Vat ${ }_{6}$ Met Lab ${ }_{2}$ Bar u preslice Mosk sidêcu Vat $_{10} \mid$ u preslice ] u prêslice Vat $_{6}$ sedêĉu Mosk | težeĉu ] težeĉi Vat ${ }_{10} \mid$ vl'nu ] vlnu Met Lab ${ }_{2}$ Bar vunu Vat ${ }_{10}$

${ }^{18}$ Čt(enie) ] om. $\mathrm{Vb}_{4}$ Mosk Mavr Hum praec. ti že Vinod | divleniê ] div'leniê Mosk | radi ] r'di Mavr | bl(agoslo)ve ] bl(agoslo)vi $\mathrm{Vb}_{4} \mid$ gl(agola)še ] add. ee Vinod govor'še Mavr | Nikoliže ] Nikakože $\mathrm{Lab}_{2} \mid$ deĉi ] dêĉi Hum | deĉi kraleva ] vidêna es(tb) Mosk h'ĉi kraleva Mavr | vidêna e(stb) ] vidina e(stb) veĉe Vat add. veĉe $\mathrm{Vb}_{4}$ videna e(stb) veĉe Vat ${ }_{19}$ Met Vinod Vat ${ }_{10}$ Mavr Bar k'raleva h'ĉi Mosk vidina e(stb) Lab $_{2} \mid$ vl'nu ] vlnu Vat ${ }_{6}$ Vat $_{19}$ Met Vinod Lab ${ }_{2}$ Mavr Bar v'lnu Mosk vunu Vat ${ }_{10}$

${ }^{19}$ siê ] add. že Vat ${ }_{19}$ Vinod Hum | vsakoêki ] vsa êko $\mathrm{Vb}_{4}$ Vinod Mavr Hum vsa tvoraše êko Vat ${ }_{19}$ v'sakoêki Mosk illeg. Met | ubož'stvo ] ubožastvo Vat ${ }_{6}$ Vat $_{10}$ $\mathrm{Lab}_{2}$ Bar obžstviê $\mathrm{Vb}_{4}$ ubož'stva Vat ${ }_{19}$ ubožast'vo Mosk ubož(b)stvo Met ubožastva Vinod Hum | želêjuĉi ] želijuĉi $\operatorname{Vat}_{10}$ želejuĉi Lab $_{2} \mid$ uničiženie ] uničeženie $\operatorname{Vat}_{10} \mid$ 
može ] more Mavr | iz'ves'ti ] izvesti Vat ${ }_{6}$ Met Vat $_{10}$ Lab $_{2}$ Mavr Bar izves'ti Vat ${ }_{19}$ Mosk izvês'ti Vinod iz'vêsti Hum

${ }^{20}$ Egda že ] I tıgda Vat ${ }_{19}$ om. Vinod Eg'da že Bar | posalı ] poslalı $\mathrm{Vb}_{4}$ poslı

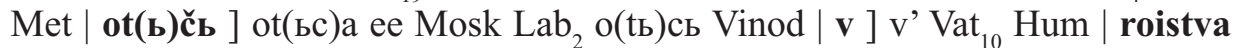
] roždeniê $\mathrm{Vb}_{4}$ rož'stva Vat ${ }_{19}$ rožds'tva Hum | vzvrati se ] vzrati se Vat ${ }_{6}$ vrati se finis Vat ${ }_{19}$ vrati se Vat ${ }_{10} \mid \mathbf{v} \mathbf{z}(\mathbf{e})$ mlju roistva svoego vzvrati se ] vrati se v' zemlju roist'va svoego Mosk

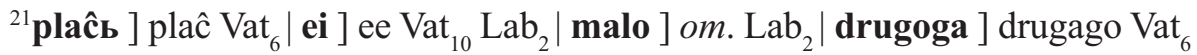
$\mathrm{Vb}_{4}$ Vinod Hum drugoga Mavr | suk'na ] suknja Vat ${ }_{6}$ sukna $\mathrm{Vb}_{4}$ Mavr Hum Bar add. sviti Vat $_{10} \mid$ imêšse ] imiše $\operatorname{Vat}_{10}$ Lab $_{2}$ Bar | lica suk'na imêše ] sukna imiše lica Met

${ }^{22}$ čt(enie) ] čteno Vat ${ }_{10}$ om. Mavr | I por'mnanie (sic!) stvori (sic!) gr'daê (sic!) rabina ] Iarmenıgardiê raba Vat ${ }_{6}$ Ir'mengardiê raba $\mathrm{Vb}_{4}$ i por'm'nanie (sic!) g'rdaê (sic!) raba učinivši (sic!) Mosk Ir'mengardiê raba Meti por'mnanie (sic!) gr'daê (sic!) raba Vinod Irmen'gardiê raba Vat ${ }_{10}$ i por'mnaniê (sic!) gar'diê (sic!) r(a)ba učuv'ši Lab ${ }_{2}$ Ir'mengar'diê r'ba Mavri por'm'nanie (sic!) stvori (sic!) g'rdaê (sic!) rabina Hum Irmengardiê raba Bar|i ] om. Vb $_{4}$ Mosk Met Vinod Vat ${ }_{10}$ Mavr $\operatorname{Bar} \mid$ slišala bê ] sliša Vat ${ }_{6} \mathrm{Vb}_{4}$ Met Vinod Vat ${ }_{10} \mathrm{Lab}_{2}$ Mavr Bar s'lišala bê Mosk b(la)ž(e)nie ] b(la)ž(e)ne Met | Elizabêti ] Elisavti Vb ${ }_{4}$ Met Elizabeti Vinod Vat ${ }_{10}$ $\mathrm{Lab}_{2}$ Bar Elisav'ti Mavr | prêžde ] i prie Vat ${ }_{6}$ prêe $\mathrm{Vb}_{4}$ prije Mosk prie Met Vat ${ }_{10}$ $\mathrm{Lab}_{2}$ Bar prêe Mavr prêž'de Hum | prestavleniê ] prêstavleniê $\mathrm{Vb}_{4}$ pres'tavleniê Mosk $\mathrm{Lab}_{2} \mid$ takoju ] tako $\mathrm{Vat}_{6} \mathrm{Vat}_{10}$ Bar takuju $\mathrm{Lab}_{2} \mid$ gl(agol)juĉu ] govoreĉu Mavr | juže ] iže Met jure Mavr | v'rême ] vrême $\mathrm{Vb}_{4} \mathrm{Lab}_{2}$ Hum vreme Mosk vrime Met $\operatorname{Vat}_{10} \operatorname{Bar} \operatorname{vr}(\hat{e})$ mena Vinod $\mid \mathbf{v}$ neže ] v' neže vr(ê)me Mosk v ko Mavr v' neže Hum | v'semogi ] vsemogi Vat ${ }_{6}$ Met Vinod Vat ${ }_{10} \operatorname{Lab}_{2}$ Hum Bar | têhь ] vsêhь $\mathrm{Lab}_{2} \mid$ iže ] ki Mavr | prizovetı ] prizvati Vat ${ }_{6}$ prizovêtb Mosk finis Mavr

${ }^{23} \mathbf{R}(\mathbf{e})$ če čto ] oĉe Vat ${ }_{6} \mathrm{r}(\mathrm{e})$ če č’to Mosk Hum | vsaki ] vsbki Met | eže ] om. Vinod | bê ] b(ê)še Vinod | prestavleniem' ] pred' prestavleniêmb Vat ${ }_{6}$ prêdstavleniem' $\mathrm{Vb}_{4}$ pres'tavleniemь Mosk predstavleniemь Met prêd' prstavleniemь Vinod pred' prest(a)vleniemь Vat ${ }_{10}$ pred' vleniemь presta $\mathrm{Lab}_{2}$ pred prestavleniemь Bar $\mid$ еe ] $a d d$. t(a)koju g(lago)ljuĉu juže vr(ê)me nsstoits v neže vs(e)mogi b(og)b têh' iže sutb priêt(e)li ego prizovetb $\mathrm{r}(\mathrm{e})$ če čto vs(a)ki d(a)nь ona blizb b(ê)še pred' prestavleniemb ee Vinod | prez'bož'na b(ê)še ] prezbožna bê $\operatorname{Vat}_{6} \mathrm{Vb}_{4}$ Vinod Bar prezbožanı bê Mosk presbožna bê Met prezbož'na bê Vat ${ }_{10}$ prêz'božan bê Lab $_{2}$ prez'božna $b(\hat{e})$ še Hum

${ }^{24} \mathbf{v}^{\prime}$ onb ] va onb Vat ${ }_{6}$ Mosk Met Vat ${ }_{10}$ Lab $_{2}$ Bar om. v'Vinod | semr'ti ] smrti $\operatorname{Vat}_{6}$ semrti Met Vat $_{10}$ Lab $_{2}$ Hum Bar $\mid$ lêki ] leki Vat ${ }_{10} \mid$ s'peĉi ] speĉa Vat ${ }_{6}$ Mosk 
Vinod $\mathrm{Lab}_{2}$ speĉi Met Vat ${ }_{10}$ Hum | leža ] lêža $\left.\mathrm{Lab}_{2} \mathrm{Hum} \mid \mathbf{i}\right]$ om. $\mathrm{Vb}_{4} \mid$ iz'daše ] izdaše Vat ${ }_{6}$ Vinod izdaše Ti že $\mathrm{Vb}_{4}$ izdše Met finis Vat ${ }_{10}$ izdaše finis Bar

${ }^{25}$ čte(nie) ] om. Vinod $\mathrm{Lab}_{2}$ Hum |četire ] $\cdot \tilde{\mathrm{g}}$ - Vat ${ }_{6}$ Mosk Met $\mathrm{Lab}_{2}$ četiri $\mathrm{Vb}_{4}$ Vinod | d(b)ni ] d'ni Hum | semr'ti ] semrti Vat ${ }_{6}$ Met Hum i semrti Lab ${ }_{2} \mid \mathbf{t}(\hat{\mathbf{e}}) \mathbf{l o}$ ] telo Mosk Met $\mathrm{Lab}_{2} \mid$ Elizabêti ] Elisavti $\mathrm{Vb}_{4}$ Met Elizabeti Mosk Vinod Lab | nepogrebeno ] pogrebeno (sic!) Vat ${ }_{6} \mathrm{Vb}_{4}$ Mosk Met Lab ${ }_{2}$ nepogrêbeno Vinod | bê ] bi $\mathrm{Lab}_{2} \mid$ nikoeže ] preac. i Mosk Met $\mathrm{Lab}_{2} \mid$ s'mrada ] smrada $\mathrm{Vat}_{6} \mathrm{Vb}_{4}$ Met Vinod Lab ${ }_{2}$ Hum | imê ] ime Mosk | êkože ] êko Mosk | ot druzêhb ] ot druzihь $\mathrm{t}(\hat{\mathrm{e}}) 1(\mathrm{e}) \mathrm{sb}$ Vat ${ }_{6} a d d$. telesь $\mathrm{Vb}_{4}$ ot d'ruzihь telesь Mosk ot druzihь telesь Met $\mathrm{Lab}_{2}$ add. t(ê)lesь Vinod Hum

${ }^{26}$ na pače ] пь p'če $\mathrm{Vb}_{4}$ пь pače Vinod | telese ] t(ê)lese Mosk Vinod Hum telesa Met | is'hoêše ] ishoêše Vat ${ }_{6}$ Met $\mathrm{Lab}_{2}$ ishoždaše $\mathrm{Vb}_{4}$ Vinod ishojaše Hum | vidêše se ] viêše se Vat ${ }_{6}$ Mosk Met $\mathrm{Lab}_{2}$ viždaše se $\mathrm{Vb}_{4}$ Vinod | ukrêplajuĉi ] ukr'eplajuĉi Mosk ukriplajuĉi Met ukreplajucii $\mathrm{Lab}_{2} \mid$ imêše ] imiše Met

${ }^{27}$ oblêčeno ] ob'lečeno Mosk oblečeno Vinod | bê ] b(ê) še Vat $\left.{ }_{6} \mid \mathbf{t}(\hat{\mathbf{e}}) \mathbf{l o}\right]$ telo Mosk Met $\mathrm{Lab}_{2} \mid$ ee ] nee Met $\mid$ sineju ] sinu $\mathrm{Vb}_{4}$ Met $\mid$ suk'neju ] suknu $\mathrm{Vb}_{4}$ sukneju $\operatorname{Vat}_{6} \mid$ sineju suk'neju ] suk'neju sineju $\mathrm{Lab}_{2} \mid$ suk'nom'] suknomb $\mathrm{Vat}_{6} \mathrm{Vb}_{4} \mathrm{Met}$ Vinod | ob'vezano ] obvezano $\mathrm{Vb}_{4}$ Met Vinod | b(o)ž(a)stviemb ] z božstvomb Vat $_{6}$ Vinod b(o)žstvomb $\mathrm{Vb}_{4}$ Mosk Met z božastvomb Lab $_{2} \mid$ vžeženi ] v'žbženi $\mathrm{Vb}_{4} \mathrm{v}^{\prime}$ žeženi Mosk vъžgani Met vžeženi $\mathrm{Lab}_{2} \mid$ lap'tace ] laptaci Vat ${ }_{6}$ laptice $\mathrm{Vb}_{4}$ lsptce Met | suk'na ] sukna Vat ${ }_{6} \mathrm{Vb}_{4}$ Met Hum | urêzovahu ] obrazovahu Vat otrêzovahu $\mathrm{Vb}_{4}$ otrêzivahu Mosk urizovahu Met odrizovahu Vinod otrizovahu $\mathrm{Lab}_{2}$ urêzivahu Hum $\mid$ a druzi ] om. $\mathrm{Vat}_{6} \mathrm{Vb}_{4}$ Mosk Met $\mathrm{Lab}_{2} \mid$ nohat ] i ot nohatb $\mathrm{Vat}_{6}$ i nohats $\mathrm{Vb}_{4}$ praec. i Mosk Met nohats Vinod i nohatı $\mathrm{Lab}_{2} \mid$ ini že ] a druzi $\mathrm{Vat}_{6} \mathrm{Vb}_{4}$ Met Vinod Lab ${ }_{2}$ a d'ruzi Mosk | vlass ] vlasi Vat ${ }_{6} \mathrm{v}^{\prime}$ lass Mosk | ee ] add. Ti že g(ospod)i $\mathrm{Vb}_{4}$ add. T(i) že Hum

${ }^{28} \mathbf{v}$ si d(a)nb ] V d(a)nь s(ve)tie Elizabêti Vat ${ }_{6}$ Hum V d(a)nb s(ve)tie Elisavti $\mathrm{Vb}_{4} \mathrm{~V}$ d(a)nь s(ve)te Elizabêti Pm Na d(a)nь s(ve)te Elisavti Met V' d(a)nь s(ve)tie Elizabeti Vinod N(a) d(a)nь s(ve)te Elizabeti Lab 2 V d(a)nь s(ve)te Elisav'ti Mavr | ničtože ] nič'tože $\mathrm{Lab}_{2}$ Hum niĉ' Mavr | budi ] ne b(u)di Mavr | s(veta)go ] om. Mavr $\mid$ Ponciêna ] Pon'ciêna $\mathrm{Vb}_{4} \mathrm{Lab}_{2}$ Mavr Hum $\mid$ na ] praec. $\mathrm{nb}^{\mathrm{Vb}} \mathrm{Vb}_{4}$ čtuet se ] čte se Vat ${ }_{6}$ čtui se Met čtuet' se Vinod | v si d(a)nb ničtože budi ot s(veta)go Ponciêna $\cdot$ na ini d(a)nb čtuet se ] om. Vat ${ }_{19}$ Mosk | na ini d(a)nb čtuet se ] om. $\mathrm{Lab}_{2} \mathrm{Mavr}$ 


\section{Bibliografija}

Hrvatskoglagoljski izvori

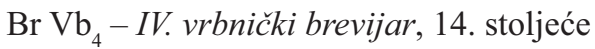

$\mathrm{Br} \mathrm{Pm}$ - Pašmanski brevijar, druga polovina 14. i 15. stoljeća

Br Vat $_{6}$ - Vatikanski brevijar Illirico 6, sredina - treća četvrtina 14. stoljeća (1379.?)

$\mathrm{Br} \mathrm{Lab}-$ I. ljubljanski (beramski) brevijar, kraj 14. stoljeća

Br Mosk - Moskovski brevijar, oko 1442. - 1443.

Br Met - Brevijar Metropolitanske knjižnice, 1442.

$\mathrm{Br}_{1}-$ I. novljanski brevijar, 1459.

Br Mavr - Brevijar popa Mavra, 1460.

Br Hum - Humski brevijar, 15. stoljeće

$\mathrm{Br} \mathrm{Vat}_{19}$ - Vatikanski brevijar Vat. Slav. 19, 1465.

Br Vinod -Vinodolski brevijar (Kukuljevićev), 1485.

$\mathrm{Br} \mathrm{Vat}_{10}$ - Vatikanski brevijar Illirico 10, 1485.

$\mathrm{Br} \mathrm{Lab}_{2}$ - II. ljubljanski (beramski) brevijar, 15. stoljeće

Br Bar-Baromićev brevijar, 1493.

COxf-Oxfordski zbornik, 15. stoljeće

$\mathrm{MVat}_{4}$ - Vatikanski misal Illirico 4, početak 14. stoljeća

\section{Literatura}

BAŠIĆ, Petar. 2004. Franjevački sveci XII.-XV. stoljeća u hrvatskoglagoljskim kalendarima. U Glagoljica i hrvatski glagolizam. Zbornik radova s međunarodnoga znanstvenog skupa povodom 100. obljetnice Staroslavenske akademije i 50. obljetnice Staroslavenskog instituta (Zagreb - Krk 2.-6. listopada 2002.), ur. Marija-Ana Dürrigl, Milan Mihaljević, Franjo Velčić, 237-246. Zagreb-Krk: Staroslavenski institut, Krčka biskupija.

BENEDIKT XVI. 2010. Elizabeta Ugarska - svetica siromaha. Kateheza pape Benedikta XVI. na općoj audijenciji, 20. listopada 2010. Libreria Editrice Vaticana. http://w2.vatican.va/content/benedict-xvi/hr/audiences/2010/documents/hf_benxvi_aud_20101020.html (posjet 18.9.2014).

ČASOSLOV 1985. Časoslov rimskog obreda IV. Vrijeme kroz godinu XVIII-XXXIV. Zagreb: Kršćanska sadašnjost.

Die 10 Euro Gedenkmünze „,800. Geburtstag Elisabeth von Thüringen“. http://www. mdm.de/10-euro-silber-gedenkmunze-800-geburtstag-elisabeth-von-thuringen (posjet 20. 10. 2014).

FRANKOVIĆ, Đuro. 2010. Sv. Stjepan i sv. Ladislav u pučkoj tradiciji mađarskih Hrvata. Cris 1: 195-201.

FRANJEVAČKI IZVORI 2012. Fontes franciscani. Ur. Pero Vrebac. Sarajevo-Zagreb: Vijeće franjevačkih zajednica Hrvatske i Bosne i Hercegovine.

GORYS, Erhard 2003. Leksikon svetaca. Jastrebarsko: Naklada Slap. 
HCSL 2014. Hrvatski crkvenoslavenski jezik. Prir. Milan Mihaljević. Zagreb: Hrvatska sveučilišna naklada, Staroslavenski institut.

KLANICZAY, Gábor. 2002. Holy Rulers and Blessed Princesses: Dynastic Cults in Medieval Central Europe. Cambridge: Cambridge University Press.

MARULIĆ, Marko. 2010. Upućivanje u čestit život po primjerima svetaca. Preveo, komentirao i priredio Branimir Glavičić. Zagreb: Nakladni zavod Globus.

MEDIEVAL SOURCEBOOK. The Golden Legend: Volume 6. The Life of S. Elisabeth [of Hungary] http://www.fordham.edu/halsall/basis/goldenlegend/GoldenLegend-Volume6.asp\#Elizabeth (posjet 19. 12. 2014).

PANTELIĆ, Marija Agnezija. 2013. Hrvatsko glagoljsko srednjovjekovlje. Prir. Petar Bašić. Zagreb: Kršćanska sadašnjost, Družba sestara milosrdnica Svetog Vinka Paulskog.

PIEPER, Lori. 2002. St. Elizabeth of Hungary and the franciscan tradition. Dissertation submitted in partial fulfilment of the requirements for the degree of doctor of philosophy in the Department of history at Fordham University. New York: Fordham University.

RAUKAR, Tomislav. 1997. Hrvatsko srednjovjekovlje: prostor, ljudi, ideje. Zagreb: Školska knjiga.

RCJHR 2011. Rječnik crkvenoslavenskoga jezika hrvatske redakcije. 18. sveščić: edinosuĉstvie-erênešb. Zagreb: Staroslavenski institut.

SLOVNÍK 1968. Slovník jazyka staroslověnského. Lexicon linguae palaeoslovenicae. Praha: Československá akademie ved. Ústav jazyků a literatur.

WOLF, Kenneth Baxter. 2010. The Life and Afterlife of St. Elizabeth of Hungary: testimony from her canonization hearings. Translated with notes and interpretive essays by Kenneth Baxter Wolf. New York: Oxford University Press.

\section{Woman, Mother, Saint: Elizabeth of Hungary in Latin and Croatian Glagolitic sources}

A royal descendant, „the greatest woman of the German Middle Ages“, beloved and loving wife and mother, devoted caretaker of the poor, homeless and sick, wellknown for her contemplative piety, self-mortification and commitment to the ideal of voluntary poverty, saint Elizabeth of Hungary / of Thurungia (1207 - 1231) was the first canonized woman of the Franciscan spirituality and, obviously, the most convenient choice for the patroness of the tertiaries, i. e. Third Order of st. Francis and Secular Franciscan Order.

Literary evidences of Elisabeth's popularity in the middle Ages and beyond are two Latin immensely popular texts: Legenda aurea (cca. 1260) by Italian chronicler and archbishop of Genoa Jacobus de Voragine and De institutione bene vivendi per exempla sanctorum (cca. 1496) by Croatian Christian humanist Marko Marulić of Split. In the first one, Elisabeth is one of only five contemporary $\left(12^{\text {th }}\right.$ and $13^{\text {th }}$ century) saints whose story is told by de Voragine and the only woman among 
them. In the second one, being a collection of moral stories and anecdotes from the Bible and from the lives of numerous saints, Elisabeth is the most referred to and praised woman after Blessed Virgin Mary.

Owing to the fact that canonization of Elisabeth was one of the first papally driven and formalized canonization processes, reliable sources about her life have been preserved until our time. The most extensive and important among them is known as the Dicta quatuor ancillarum (1235). Dicta includes testimonies from Elisabeth's close female companions Guda, Isentrud, Irmgard and Elisabeth. The outstanding quality of Dicta is its female perspective which provides an outspoken point of view accompanied by many interesting details of st. Elisabeth's everyday life. De Voragine and Marulić both used Dicta as their primary source of information abour Elisabeth but they adjusted it according to their understanding of Elisabeth's life (in terms of her marriage) and the purposes of their respective texts. It seems as the fact that while being married she was beloved and loving wife didn't completely fit in their (medieval) conception of the female saint.

Considerably shortened Croatian Church Slavonic translation of the Dicta quatuor ancillarum, based on well selected portions of the original text, can be found in the Croatian Glagolitic breviaries $\left(14^{\text {th }}-15^{\text {th }}\right.$ century $)$ as a part of the Office of readings for st. Elisabeth ( $19^{\text {th }}$ November). The Glagolitic text from $I$. Ljubljana breviary is published in the Latin script transliteration accompanied with the critical apparatus comprising all known versions of the reading preserved in the Croatian Glagolitic breviaries (13 of them). The significance of this reading emerges not only from the fact that contemporary breviaries do not contain it any more (it is replaced by a short version of Summa vitae by Elisabeth's confessor Conrad of Marburg), but also from the fact that it had enriched Croatian medieval literacy with Dicta's female straightness and openness. Being written in vernacular and not Latin, like all the previously mentioned sources, it contributed to the strenghtening of st. Elisabeth's cult and Franciscan spirituality, but most of all to the overall democratization and accessibility of the medieval literature and literacy itself.

Keywords: Elisabeth of Hungary, Croatian glagolitic sources, Dicta quatuor ancillarum, Legenda aurea, De institutione bene vivendi per exempla sanctorum

Ključne riječi: Elizabeta Ugarska, hrvatskoglagoljski izvori, Dicta quatuor ancillarum, Zlatna legenda, Upućivanje u čestit život s primjerima svetaca

Ana Kovačević

Staroslavenski institut HR-10000 Zagreb, Demetrova 11 akovacevic@stin.hr 


\section{FILOZOFSKI FAKULTET SVEUČILIŠTA U ZAGREBU \\ ZAVOD ZA HRVATSKU POVIJEST \\ INSTITUTE OF CROATIAN HISTORY \\ INSTITUT FÜR KROATISCHE GESCHICHTE}
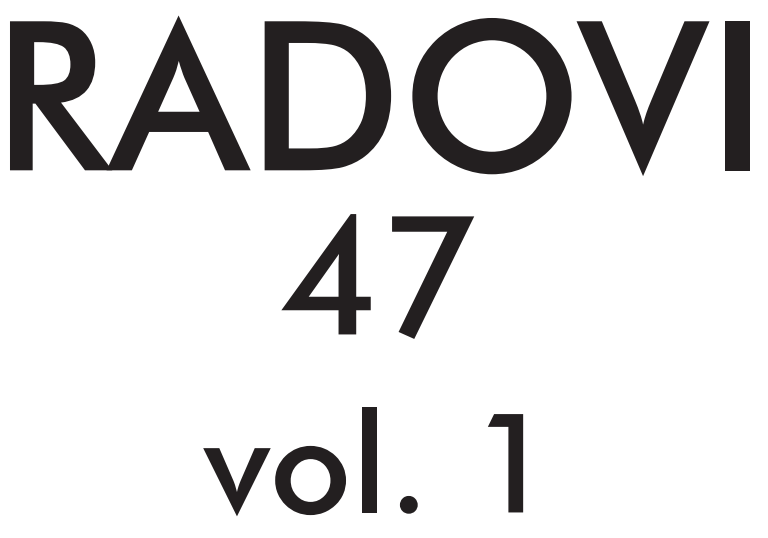

ZAVOD ZA HRVATSKU POVIJEST

FILOZOFSKOGA FAKULTETA SVEUČILIŠTA U ZAGREBU

\section{PF press \\ ZAGREB 2015.}




\title{
RADOVI ZAVODA ZA HRVATSKU POVIJEST FILOZOFSKOGA FAKULTETA SVEUČILIŠTA U ZAGREBU
}

\author{
Knjiga 47, vol. 1
}

\author{
Izdavač / Publisher \\ Zavod za hrvatsku povijest \\ Filozofskoga fakulteta Sveučilišta u Zagrebu \\ FF-press \\ Za izdavača / For Publisher \\ Vlatko Previšić \\ Glavni urednik / Editor-in-Chief \\ Hrvoje Gračanin \\ Izvršna urednica / Executive Editor \\ Inga Vilogorac Brčić \\ Uredništvo / Editorial Board
}

Bruna Kuntić-Makvić (stara povijest/ancient history), Zrinka Nikolić Jakus (srednji vijek/ medieval history), Hrvoje Petrić (rani novi vijek/early modern history), Željko Holjevac (moderna povijest/modern history), Tvrtko Jakovina (suvremena povijest/contemporary history),

Silvija Pisk (mikrohistorija i zavičajna povijest/microhistory and local history),

Zrinka Blažević (teorija i metodologija povijesti/theory and methodology of history)

Međunarodno uredničko vijeće / International Editorial Council

Denis Alimov (Sankt Peterburg), Živko Andrijašević (Nikšić), Csaba Békés (Budapest), Rajko Bratož (Ljubljana), Snježana Buzov (Columbus, Ohio), Svetlozar Eldarov (Sofija), Toni Filiposki (Skopje), Aleksandar Fotić (Beograd), Vladan Gavrilović (Novi Sad), Alojz Ivanišević (Wien),

Egidio Ivetić (Padova), Husnija Kamberović (Sarajevo), Karl Kaser (Graz),

Irina Ognyanova (Sofija), Géza Pálffy (Budapest), Ioan-Aurel Pop (Cluj),

Nade Proeva (Skopje), Alexios Savvides (Kalamata), Vlada Stanković (Beograd), Ludwig Steindorff (Kiel), Peter Štih (Ljubljana)

Izvršna urednica za tuzemnu i inozemnu razmjenu / Executive Editor for Publications Exchange Kristina Milković

Tajnik uredništva / Editorial Board Assistant

Dejan Zadro

Adresa uredništva/Editorial Board address

Zavod za hrvatsku povijest, Filozofski fakultet Zagreb, Ivana Lučića 3, HR-10 000, Zagreb

Tel. ++385 (0)1 6120 150, 6120 158, faks ++385 (0)1 6156879

Časopis izlazi jedanput godišnje / The Journal is published once a year

Časopis je u digitalnom obliku dostupan na / The Journal in digital form is accessible at Portal znanstvenih časopisa Republike Hrvatske „Hrčak“ http://hrcak.srce.hr/radovi-zhp

Financijska potpora za tisak časopisa / The Journal is published with the support by

Ministarstvo znanosti, obrazovanja i športa Republike Hrvatske

Časopis je indeksiran u sljedećim bazama / The Journal is indexed in the following databases:

Directory of Open Access Journals, EBSCO, SCOPUS, ERIH PLUS 
Naslovna stranica

Iva Mandić

Grafičko oblikovanje i računalni slog

Marko Maraković

Lektura

Samanta Paronić

Tisak

Web2tisak, Zagreb

Naklada

250 primjeraka

Časopis je u digitalnom obliku dostupan na Portalu znanstvenih časopisa Republike Hrvatske ,Hrčak“ http://hrcak.srce.hr/radovi-zhp

The Journal is accessible in digital form at the Hrcak - Portal of scientific journals of Croatia http://hrcak.srce.hr/radovi-zhp 


\section{RADOVI 47}

\section{vol. 1}

ZaVoda za hrVAtSku poviJest FILOZOFskoga fakulteta SVeuČILIŠTA u Zagrebu 


\title{
Tematski blok / Themed issue
}

\section{TREĆOREDSKA GLAGOLJAŠKA TRADICIJA U EUROPSKOM KONTEKSTU TERTIARY GLAGOLITIC TRADITION IN EUROPEAN CONTEXT}

\author{
Radovi međunarodnoga znanstvenog skupa \\ održanoga 27. i 28. IX. 2013. na Hrvatskom katoličkom sveučilištu u Zagrebu \\ u organizaciji \\ Provincije franjevaca trećoredaca glagoljaša u Zagrebu, Hrvatskoga katoličkog \\ sveučilišta u Zagrebu, Filozofskoga fakulteta Sveučilišta u Zagrebu - Odsjek za \\ povijest, Filozofskoga fakulteta Sveučilišta u Splitu - Odsjek za povijest, Instituta \\ za povijest umjetnosti u Zagrebu i Staroslavenskoga instituta u Zagrebu \\ Proceedings of the International Scientific Conference \\ held on 27th and 28th September 2013 at the Catholic University of Croatia in Zagreb \\ and organized by \\ the Province of the Glagolitic Friars of the Third Order Regular, Catholic University \\ of Croatia in Zagreb, Faculty of Humanities and Social Sciences of the University \\ of Zagreb - Department of History, Faculty of Humanities and Social Sciences of \\ the University of Split - Department of History, Institute of Art History, \\ and Old Church Slavonic Institute
}

Gosti urednici / Guest editors

\author{
Ivan BOTICA \\ Tomislav GALOVIĆ \\ Kristijan KUHAR
}

